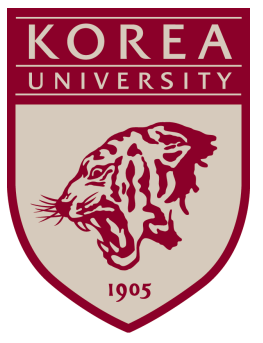

Discussion Paper Series

No. 1503

June 2015

Happily ever after? Intrahousehold bargaining and the distribution of utility within marriage

Dirk Bethmann and Robert Rudolf

The Institute of Economic Research - Korea University

Anam-dong, Sungbuk-ku, Seoul, 136-701, South Korea, Tel: (82-2) 3290-1632, Fax: (82-2) 928-4948

Copyright (C) 2015 IER. 


\title{
Happily ever after? Intrahousehold bargaining and the distribution of utility within marriage
}

\author{
By Dirk Bethmann ${ }^{\mathrm{a}}$ and Robert Rudolf ${ }^{\mathrm{b}}$ \\ ${ }^{\text {a }}$ Department of Economics, Korea University \\ 145, Anam-ro, Seongbuk-gu, Seoul 136-701, South Korea \\ ${ }^{\mathrm{b}}$ Corresponding author: \\ Division of International Studies, Korea University \\ 145, Anam-ro, Seongbuk-gu, Seoul 136-701, South Korea \\ Tel. +82-2-3290-2413, rrudolf@korea.ac.kr
}

\begin{abstract}
:
Using a rich longitudinal data set of married couples from the Korean Labor and Income Panel Study (KLIPS), this article seeks to uncover the relationship between intrahousehold bargaining and the distribution of experienced utility within marriage. Providing an empirical test of the cooperative bargaining model, we confirm both substantial gains from marriage and the importance of the exogenous threat point in the distribution of happiness within the household. In particular, we find that the higher a partner's relative predicted earnings outside of marriage, the higher her/ his relative gains from marriage. In addition, this study reveals an asymmetry between women and men in older couples: men on average are endowed with a lower threat point utility, yet secure higher returns from marriage. This is likely to be due to social norms and prescribed gender roles which are more prevalent within the older generation.
\end{abstract}

JEL: C78, D10, I31, J12, J16

Keywords: Intrahousehold bargaining; Marriage; Happiness; Gender asymmetry; Generation effect. 
It is the law of nature that woman should be held under the dominance of man.

(Confucius, 551-479 BCE)

\section{Introduction}

Until recently, measuring utility directly was thought of to be impossible by neoclassical economists. Thus, scholars contented themselves with studying the symptoms of utility, rather than utility itself, using revealed preferences such as consumption choices and time allocation. After two decades of steady growth in the happiness economics literature, however, the picture has changed. Advancements in data quality, in the measurement of subjective well-being (SWB), as well as in statistical techniques compatible with SWB data has allowed economists to look at "experienced" utility in a more direct manner. The rise of happiness economics in part means returning to the roots of utility (Kahneman et al., 1997). In fact, Jeremy Bentham coined the terms utility and utilitarianism to describe what he called the 'Highest Happiness Principal'. Two centuries after Bentham, economists use measures of self-reported happiness and satisfaction in a growing variety of econometric applications such as unemployment, income \& wealth, health, marriage, etc. (Easterlin, 1974; Clark and Oswald, 1994; Luttmer, 2005; Gardner and Oswald, 2007; Clark et al., 2008; Deaton, 2008; Dolan et al., 2008; van Praag and Ferrer-i-Carbonell, 2008; Stiglitz et al., 2009; Layard, 2010).

The literature on intrahousehold bargaining and allocation of resources has strongly relied on the revealed preference approach to make predictions about the allocation of utility within families. Since the landmark works of Manser and Brown (1980) and McElroy and Horney (1981) it has generally been found that incomes within households are not pooled, but rather that expenditures depend on the relative bargaining power of individual family members (Thomas, 1990; Hoddinott and Haddad, 1995; Lundberg et al., 1997; Duflo, 2003; Brown, 2009; Li and Wu, 2011; Doss, 2013). Bargaining power furthermore depends on resources controlled by each spouse, in particular resources held outside of marriage. Men are usually found to spend a higher share of their income on goods for their personal consumption, while women are more likely to purchase goods for children and for general household usage. Higher female bargaining power has further been found to be associated with increased time spent in household chores by husbands and 
increased leisure time of wives (Bittman et al., 2003; Brown, 2009). Stevenson and Wolfers (2006) have shown that an exogenous increase in female bargaining power decreased domestic violence in the U.S. In those states that adopted unilateral divorce legislation, the authors found an increase in the likelihood that a domestic violence relationship ends, a 30 percent decline in domestic violence for both women and men, an 8-16 percent decline in female suicide, as well as a 10 percent decline in females murdered by their partners.

In this article, we suggest to combine the two strands of literature presented above. Thus, we aim to empirically test the predictions of a standard bargaining model using a direct measure of utility, self-reported life satisfaction. To the best of our knowledge, this is the first paper to thoroughly estimate this relationship. We chose the case of Korea for our empirical analysis for two reasons: First, being a highly developed country, data sets provided are both of high quality and substantial time series length. We are able to use six annual waves of a rich longitudinal data set (Korean Labor and Income Panel Study, KLIPS) from 2003 to 2008. Second, although highly developed in economic sense, Korea significantly lags behind when it comes to gender equality. Traditional gender roles continue to play a significant role in Korean family and overall social life despite fast economic catch-up over the past six decades. Their legitimacy is usually drawn from Neo-Confucianism, which continues to exert a substantial influence on the Korean zeitgeist at the beginning of the $21^{\text {st }}$ century. Neo-Confucianist ideals, which include patriarchic social and family structures, are prevalent across all age groups, yet most strongly within the older generation (Yang, 2003; Jang et al., 2009). A wife is expected to serve her husband, her children and her in-laws in the household. A husband is expected to manage all affairs outside the home. Thus, until today Korean labor markets are notorious for gender discrimination in hiring, pay, and promotion; a problem exacerbated for married mothers (Yoo, 2003). In international rankings of gender equality, Korea lacks far behind other developed countries. While the country was ranked $15^{\text {th }}$ in the world in the 2014 Human Development Index, it only ranked $117^{\text {th }}$ in the Global Gender Gap index in that same year. The Korean gender gap is often associated to high levels of gender pay discrimination, labor market segregation and traditional social norms that tend to hold women back from pursuing own careers (Yoo, 2003; Jang et al., 2009).

In a very recent study, Ham and Song (2014) also use the KLIPS data set for the estimation of a bargaining model. Using information on transfer payments of young Korean couples to 
spousal parents, their regression results indicate a slightly higher bargaining power for wives. When using experienced utility, we find no difference in relative spousal benefits from marriage within young couples. Within older couples, however, we find that men benefit significantly more from marriage than their spouses. This is even true after the marital union is dissolved: divorced men experience a greater utility loss than their female counterparts. The estimated gender difference seems to reflect the distinctive roles women and men - both unwed and married - have in the Korean society, and how these roles are changing over time. We argue that it is in line with Akerlof and Kranton's (2000) theory of identity.

\section{Theoretical Model}

Marriage can be viewed as a cooperative partnership that helps rational individuals realize utility gains from joint consumption and production. The economic literature has identified several such sources of gains including the division of labor to exploit increasing returns or comparative advantages, the provision of credit when capital markets are imperfect, the production and consumption of public goods, and risk sharing (see Weiss, 1997, for an excellent overview). In this section we briefly illustrate key concepts and focus on the gain from a (local) public good. ${ }^{1}$

We assume separable utility from the consumption of the private good $\left(c_{i}\right)$ and the public family good $(g)$. Let functions $U\left(c_{i}\right)$ and $V\left(g_{i}\right)$ represent the respective utility levels. Individuals are subject to a budget constraint:

$$
y_{i}=c_{i}+p g
$$

where $y_{i}$ summarizes wealth, time and other economic resources that are available to individual $i$. Parameter $p$ is the price of the public family good relative to the private good. Under singlehood, individual $i$ chooses $g_{i}$ to maximize $U\left(c_{i}\right)+V\left(g_{i}\right)$ subject to (1), which leads to the following standard first order condition:

\footnotetext{
${ }^{1}$ We consider goods that are (locally) public from the perspective of members of the same household, hence the expression public family good.
} 


$$
M R S_{i}^{S}=\frac{V^{\prime}\left(g_{i}^{S}\right)}{U^{\prime}\left(c_{i}^{S}\right)}=p
$$

where $g_{i}^{S}$ and $c_{i}^{S}$ are the optimal choices when living in singlehood. At the optimum, the marginal rate of substitution $(M R S)$ between the two goods should equal the marginal cost of obtaining the public good (relative to the private good: $p$ ) such that the allocation of resources is efficient. With only one member in the household there are no external effects that one might fail to internalize.

Next, we discuss the case where individuals $i$ and $j$ form a non-cooperative union. We assume that the joint provision of the public family good is given by the sum of individual contributions:

$$
g=g_{i}+g_{j}
$$

When behaving non-cooperatively, contributions of individual $i$ are taken as given by individual $j$ and vice versa (in the following this is indicated by the bars) such that the two first order conditions are given by:

$$
\frac{V^{\prime}\left(g_{i}^{n}+\bar{g}_{j}\right)}{U^{\prime}\left(c_{i}^{n}\right)}=\frac{V^{\prime}\left(\bar{g}_{i}+g_{j}^{n}\right)}{U^{\prime}\left(c_{j}^{n}\right)}=p,
$$

where the superscript $n$ denotes the optimal choices in a non-cooperative union. Note that in this case the provision of the public good is inefficient. To see this we merely have to check Samuelson's condition which relates the sum of individual marginal rates of substitution to the marginal cost of providing the public $\operatorname{good}(p):^{2}$

$$
M R S_{i}^{n}+M R S_{j}^{n}=2 p>p
$$

The sum of marginal rates of substitution between the public and the private goods exceeds the marginal cost of providing the public good. As a consequence the non-cooperative union is characterized by an under provision of the public family good and there is a potential for a Pareto improvement.

\footnotetext{
${ }^{2}$ See Samuelson (1954).
} 
Singlehood in equations (1) and (2) but also the non-cooperative case in (4) and (5) are both of importance to a cooperative bargaining model of marriage because both of them can be viewed as the fallback position in the case of disagreement. ${ }^{3}$ Obviously, the correct choice depends on the respective context. If children are the public family good of interest, for instance, one would probably use the non-cooperative solution as the fallback position because parental interest in children does not end with divorce. Parental efforts however most certainly cease to be coordinated because coordination is much harder if not impossible to implement after separation. If one focuses on home production instead, singlehood seems to be the appropriate choice because here dissolutions usually lead to the formation of two new households.

For the time being we use $T_{i}$ and $T_{j}$ to denote the individual threat points without making any assumption on how they are determined. In a cooperative bargaining game, the couple maximizes the following Nash product of the two excess utilities:

$$
\gamma \ln \left[U\left(y_{i}-p g_{i}\right)+V\left(g_{i}+g_{j}\right)-T_{i}\right]+(1-\gamma) \ln \left[U\left(y_{j}-p g_{j}\right)+V\left(g_{i}+g_{j}\right)-T_{j}\right] \longrightarrow \max _{g_{i}, g_{j}}
$$

Note that we have used the logarithm to turn the product into a sum. This monotonic transformation simplifies the algebra without changing results. Parameters $\gamma$ and $(1-\gamma)$ measure the bargaining power of individual $i$ and $j$ respectively. The first order conditions are hence given by:

$\frac{V^{\prime}\left(g_{i}^{c}+g_{j}^{c}\right)}{U^{\prime}\left(c_{i}^{c}\right)}=p \frac{\gamma\left[U\left(c_{j}^{c}\right)+V\left(g_{i}^{c}+g_{j}^{c}\right)-T_{j}\right]}{\gamma\left[U\left(c_{j}^{c}\right)+V\left(g_{i}^{c}+g_{j}^{c}\right)-T_{j}\right]+(1-\gamma)\left[U\left(c_{i}^{c}\right)+V\left(g_{i}^{c}+g_{j}^{c}\right)-T_{i}\right]}$

$\frac{V^{\prime}\left(g_{i}^{c}+g_{j}^{c}\right)}{U^{\prime}\left(c_{j}^{c}\right)}=p \frac{(1-\gamma)\left[U\left(c_{i}^{c}\right)+V\left(g_{i}^{c}+g_{j}^{c}\right)-T_{i}\right]}{\gamma\left[U\left(c_{j}^{c}\right)+V\left(g_{i}^{c}+g_{j}^{c}\right)-T_{j}\right]+(1-\gamma)\left[U\left(c_{i}^{c}\right)+V\left(g_{i}^{c}+g_{j}^{c}\right)-T_{i}\right]}$

where the superscript $c$ stands for the cooperative bargaining solution. Note that these findings ensure an efficient provision of the public good:

\footnotetext{
${ }^{3}$ In Manser and Brown (1980) and McElroy and Horney (1981) singlehood utility is viewed as fallback utility. In Lundberg and Pollak (1993) uncooperative behavior within marriage determines the fallback position in the bargaining game.
} 
$M R S_{i}^{c}+M R S_{j}^{c}=p$

More importantly, the first order conditions imply that the marginal rates of substitution depend positively on the value of an individual's own threat point but negatively on the partner's:

$\frac{\partial M R S_{i}}{\partial T_{i}}>0 \quad$ and $\quad \frac{\partial M R S_{j}}{\partial T_{i}}<0$

An improved outside option leads to reduced contributions to the public family good and therefore more private consumption. The partner, in turn, shifts resources from private consumption toward the public good. As a result, an improvement of individual $i$ 's threat point leaves the provision of the public family good mostly unaffected but causes a reallocation of the private consumption good from $j$ to $i$. If we let $S$ denote the maximized sum of $U$ and $V$ in the above bargaining scenario, we can use a first order Taylor approximation to quantify the influence of threat point changes on life satisfaction (experienced utility) of individual $i$ in period $t$ :

$S_{i t}=S+\frac{\partial U\left(c_{i}\right)}{\partial c} \frac{\partial c_{i}}{\partial T_{i}}\left(\nabla T_{i}\right)_{Y_{0}} \cdot\left(Y_{i t}-Y_{0}\right)+\frac{\partial U\left(c_{i}\right)}{\partial c} \frac{\partial c_{i}}{\partial T_{j}}\left(\nabla T_{j}\right)_{Y_{0}} \cdot\left(Y_{j t}-Y_{0}\right)$

where $\nabla$ denotes the gradient of the threat point function evaluated at $Y_{0}$. From equation (10), the happiness gap between individuals $i$ and $j$ can be evaluated from:

$$
\begin{aligned}
S_{i t}-S_{j t}=S- & S+\left(\frac{\partial U\left(c_{i}\right)}{\partial c} \frac{\partial c_{i}}{\partial T_{i}}-\frac{\partial U\left(c_{j}\right)}{\partial c} \frac{\partial c_{j}}{\partial T_{i}}\right)\left(\nabla T_{i}\right)_{Y_{0}}\left(Y_{i t}-Y_{0}\right) \\
& +\left(\frac{\partial U\left(c_{i}\right)}{\partial c} \frac{\partial c_{i}}{\partial T_{j}}-\frac{\partial U\left(c_{j}\right)}{\partial c} \frac{\partial c_{j}}{\partial T_{j}}\right)\left(\nabla T_{j}\right)_{Y_{0}}\left(Y_{j t}-Y_{0}\right)
\end{aligned}
$$

The approximations in equations (10) and (11) motivate our empirical strategy in section IV below.

[Figure 1 about here]

Figure 1 illustrates the basic concepts. Two agents, wife (w) and husband (h), form a single household. Individual utility depends on the provision of a public family good and on individual consumption of the private good. Along the utility possibility frontier (UPF) where joint income is given, one spouse's utility can only improve when the partner accepts a loss. While all points along the UPF must be considered efficient, only those marked as the core reflect reasonable 
outcomes for the Nash bargaining problem in (6) as only those points reflect the situation where both spouses gain from marriage.

\section{Data and Variables}

Data for our analysis comes from the Korean Labor and Income Panel Study (KLIPS) for the years 2003 to 2008. KLIPS is a nationally representative longitudinal study of urban Korean households, modeled after the US National Longitudinal Surveys (NLS) and Panel Study of Income Dynamics (PSID). It is conducted annually by the Korea Labor Institute, a governmentsponsored research institute. The study started in 1998 with 5,000 households and 13,783 individuals aged 15 years or older. KLIPS collects a wide range of information on individuals, such as earnings, education, family and employment backgrounds, and demographic characteristics. In addition, it offers broad information on various SWB indicators. ${ }^{4}$

For a descriptive view on the happiness distribution by sex in Korea, we use a wide sample of 16 to 80 year olds for which life satisfaction information is available. This yields a total number of 34,475 person-year observations for females and 32,436 for males. Within this larger sample, we restrict our main analysis to all married couples (first marriage only) with complete information for both spouses between ages 16 and 64. This results in a sample of 14,863 couple-year observations from 3,542 couples. In KLIPS' individual questionnaire, the question on overall life satisfaction is preceded by a set of detailed questions on the satisfaction with different aspects of life: household income, leisure life, housing environment, family relations, relations with relatives, and social relations. The exact wording of the overall life satisfaction question is then: "Overall, how satisfied or dissatisfied are you with your life?" Individuals are asked to respond according to a scale ranging from 1 ("very satisfied") to 5 ("very dissatisfied"). For the sake of easier

\footnotetext{
${ }^{4}$ The data quality KLIPS provides satisfies highest international standards. The panel maintains $76.5 \%$ of the original sample throughout all waves, which is comparable to the PSID (78\%); the German Socio-economic Panel (GSOEP, 79\%); and the British Household Panel Survey (BHPS, $77 \%$ ). Kang (2010) shows that potential bias produced by attrition is negligible in KLIPS data.
} 
interpretation, we recode the scale so that higher numbers correspond to higher levels of satisfaction.

Table A1 in the appendix shows the distribution of life satisfaction for the wide sample of 16-80 year olds by sex. About half of all women and men report to be "neither satisfied nor dissatisfied". More people report to be "satisfied" than "dissatisfied". The Korean sample shows consistency of the scales applied across sexes. ${ }^{5}$ The fact that both sexes use the same scale in evaluating happiness justifies our approach to use the self-reported happiness difference between married spouses as a dependent variable below.

Table A1 indicates that female and male happiness in Korea is, on average, distributed fairly equal over the life cycle. Yet, these overall averages hide much of the channels through which happiness is actually achieved - which can differ largely between women and men. Without claiming any causality, Table 1 reports simple OLS regressions and provides a first overview on the distribution of life satisfaction by sex when controlling for a number of key factors that influence individual happiness. ${ }^{6}$

\section{[Table 1 about here]}

Controlling only for age effects in column 1 , no sex difference in happiness is found. Once we control, however, for marriage and an interaction term between sex and marriage, women are found to be significantly happier than men. This is in line with Alesina et al. (2004) who find women to be happier in both the US General Social Survey (GSS) and the Eurobarometer. Two more results are noteworthy in Table 1: First, as expected, being married is positively related to one's life satisfaction. Second, men benefit significantly more from marriage than women. This relatively higher marital gain for men keeps growing as more control variables are added in columns 3 through 6 . According to column 6 , ceteris paribus, men's happiness gains from marriage are more than three times as high as women's. At the same time, women's naturally higher endowment with life satisfaction has grown from 0.033 to 0.166 . Thus, rather than equality in

\footnotetext{
${ }^{5}$ A simple means test indicates no significant difference in the two distributions ( $\left.t=-0.805\right)$.

${ }^{6}$ For the description of individual variables see Table A2 in the appendix.
} 
happiness, it seems that women are naturally happier than men, yet men benefit more from marriage. ${ }^{7}$

Rudolf and Kang (2015) in a recent paper point towards this Korean marital gender happiness gap. However, the fact that men benefit more from marriage is not unique to the Korean case. Corra et al. (2009), using GSS data, found men to report higher happiness with their marriage in both Black and White couples in the US. They further show that over the past 30 years Black wives have closed the gap to their husbands. The authors speculate that this catch-up might have been due to improvements in the work environment for Black women relative to Black men.

As suggested by Bertrand et al. (2013), gender identities and the extent to which they are accomplished within a couple can have implications for couple happiness. For example, while advances in gender equality have been achieved over the last decades in many countries around the world, men continue to be considered the main breadwinner and thus are expected to bring home more income than their spouses. In households which deviate from this social norm, conflict might arise and even the likelihood of marital breakup rises.

Using individual earnings information from KLIPS, we can construct the share of each spouse in total couple earnings. Individual labor income of wife and husband consists of the average monthly gross earnings in wage- and self-employment. Figure 2 illustrates the relationship between wives' shares in couple earnings and relative spousal happiness in Korea.

[Figure 2 about here]

According to Figure 2, husbands on average report higher life satisfaction than wives as long as they fulfill the main breadwinner's role, i.e. as long as they bring home most of the earnings. As soon as women's share in couple earnings surpasses the perfect-equality threshold of 0.5 , the gender happiness gap reverses and women report higher life satisfaction than men. Note that the sample average of wives' share in couple earnings is 0.21 , which is illustrated by the first vertical

\footnotetext{
${ }^{7}$ Note that Table 1's results also hold when only estimated over married and never married, i.e. when excluding separated, divorced, widowed, and remarried individuals.
} 
line. Therefore, only a small fraction (11.7 percent) of households exist where the wife earns more (to the right of the second vertical line).

\section{Bargaining Analysis}

\section{IV.1 Estimation technique}

This section outlines the empirical strategy to account for the happiness allocation within married couples in Korea. Two types of estimation are used in the following: In a first simple model, differences in spousal happiness are regressed on actual earnings. In a second model, a two-step approach will be applied. For the two-step approach, the earnings potential of each spouse in the hypothetical case of marital breakup is predicted based on estimated coefficients of earnings regressions run over sex-specific samples of divorced, separated, and remarried individuals in KLIPS. Thus, the question that we ask is: given the current characteristics of each spouse, how much would he or she be able to earn outside of marriage. Predicted earnings potential will then be used instead of actual earnings to proxy each spouse's threat point in equations (10) and (11).

Having multiple waves per couple at our disposal, we can exploit the dynamic nature of the KLIPS data set in order to estimate the relationship between relative spousal earnings (potential) and relative spousal experienced utility. Subjective well-being measures are known to have a strong time-persistent component. These individual fixed effects can be attributed to largely timeinvariant personality differences (Lykken and Tellegen, 1996). Since not controlling for these differences can lead to biased results, it is essential to use fixed effects estimators when working with SWB measures. Motivated by theoretical equation (11), the difference of life satisfaction between husband and wife for a given couple in a given year will be the dependent variable of our main empirical model. Using the spousal difference rests on two assumptions. First, it assumes that women and men use life satisfaction scores in the same way when expressing their true wellbeing. Second, it also assumes that life satisfaction can be treated as a cardinal measure. The first assumption holds when comparing female and male distribution of the entire Korean sample in Table A1 which is representative for the urban Korean population. No significant differences were 
found in the way that women and men apply life satisfaction labels. As for the second assumption, Ferrer-i-Carbonell and Frijters (2004) point out that assuming cardinality or ordinality of SWB measures produces very similar results. This has been confirmed for KLIPS data by Rudolf (2014).

\section{IV.1.1 Actual earnings}

The basic model we estimate using actual spousal earnings is adopted from equations (10) and (11) in the theory section. Equation (12) presents the empirical equation for experienced utility of husband $i$ who is married to wife $j$ (conjointly forming couple $c$ ) in period $t$.

$S_{i t}=\beta_{11} \ln Y_{i t}+\beta_{12} \ln Y_{j t}+\ln Y_{c t}^{\prime} \beta_{13}+X_{c t}^{\prime} \gamma_{1}+\mu_{i}+v_{t}+\varepsilon_{i t}$

$i, j, c=1, \ldots, N \quad t=1, \ldots, T$

$Y_{i t}$ and $Y_{j t}$ represent individual earnings of husband and wife, respectively. In addition, $Y_{c t}$ denotes a vector including further household-level income variables: average monthly household percapita income, and the provincial average of monthly household per-capita income. The latter is included in order to capture relative income effects (e.g. Luttmer, 2005; Clark et al., 2008).

Additional standard control variables for the couple's household are contained in vector $X_{c t}$. It includes information on demographic characteristics of husband, wife, and the household they live in. It further includes the couple's employment and health information, as well as provincial fixed effects. Finally, $\mu, v$, and $\varepsilon$ are stochastically well-behaved terms. Individual fixed effects are captured in $\mu_{i}$ and time fixed effects in $v_{t}$.

Wife's happiness equation is equivalent to equation (12):

$S_{j t}=\beta_{21} \ln Y_{i t}+\beta_{22} \ln Y_{j t}+\ln Y_{c t}^{\prime} \beta_{23}+X_{c t}^{\prime} \gamma_{2}+\mu_{j}+u_{t}+\varepsilon_{j t}$

Further, one might find it interesting to examine the determinants of joint couple happiness. Thus we can estimate the following equation:

$S_{i t}+S_{j t}=$ 
$\left(\beta_{11}+\beta_{21}\right) \ln Y_{i t}+\left(\beta_{12}+\beta_{22}\right) \ln Y_{j t}+\left(\beta_{13}+\beta_{23}\right) \ln Y_{c t}^{\prime}+\left(\gamma_{1}+\gamma_{2}\right) X_{c t}^{\prime}+\mu_{i}+\mu_{j}+v_{t}+u_{t}+$

$\varepsilon_{i t}+\varepsilon_{j t}$

Most importantly, however, we are interested in the distribution of experienced utility and its determinants, as motivated by theoretical equation (11). This can be estimated by taking the difference of life satisfaction of husband and wife as dependent variable:

$S_{i t}-S_{j t}=$

$\left(\beta_{11}-\beta_{21}\right) \ln Y_{i t}+\left(\beta_{12}-\beta_{22}\right) \ln Y_{j t}+\left(\beta_{13}-\beta_{23}\right) \ln Y_{c t}^{\prime}+\left(\gamma_{1}-\gamma_{2}\right) X_{c t}^{\prime}+\mu_{i}-\mu_{j}+v_{t}-u_{t}+$

$\varepsilon_{i t}-\varepsilon_{j t}$

Provided the RHS variables are exogenous, coefficients in equations (12) through (15) can be estimated consistently with a standard linear fixed-effects estimator (Ferrer-i-Carbonell and Frijters, 2004).

\section{IV.1.2 Predicted (out-of-marriage) earnings potential}

Using actual earnings as a proxy for relative bargaining power as laid out above could be considered a weak identification strategy. The labor supply decision is likely to be jointly determined by husband and wife. Thus, if the division of market hours within the married couple is not perfectly based on individual comparative advantage, but rather on other factors such as socially prescribed gender roles, actual labor income is likely to be endogenous in equations (12) through (15) above. Fortunately, our data set allows us to proceed with an alternative strategy. Instead of actual earnings we can predict individual earnings potential outside of marriage by taking advantage of a sufficiently large sample of separated, divorced, and remarried women and men in KLIPS data. Using a two-step approach, we can then obtain consistent estimates of relative bargaining power based on a divorce threat point. In the first step, the earnings potential in case of marital breakup is estimated for our married sample based on earnings regressions of the mentioned subsample of currently divorced, separated, or remarried individuals. Variables for this prediction model need to be carefully selected. Since with divorce both a person's household composition and her labor supply usually change, we can only include individual characteristics 
that remain unchanged in case of marital breakup. ${ }^{8}$ In a second step, predicted earnings potential $\left(\widehat{Y}_{i t}, \widehat{Y}_{j t}\right)$ will then be substituted for actual earnings to facilitate consistent estimation of equations (12) through (15). ${ }^{9}$

Not only is it possible to estimate predicted earnings based on the sample of separated, divorced, and remarried, but one can further estimate the actual threat point utility of every single married individual and compare it to their actual utility attained inside marriage. In order to do this, we run a simple linear regression of the standard determinants of life satisfaction on the same sample of separated, divorced, and remarried. ${ }^{10}$ In a similar fashion as above, this allows us to obtain regression coefficients by sex which in turn can be used to predict the threat point utility of those currently in marriage. The divorce threat point model implies that actual achieved utility in marriage must at least meet the level of threat point utility in order for individuals to stay married. That is, there should be a strictly non-negative excess utility from marriage (cf equation (6)).

\section{IV.2 Results}

Table 2 shows the results of estimating equation (15) using different estimation techniques and both actual and predicted earnings. Estimations were carried out over our main data set of 3,542 married couples which between 2003 and 2008 were interviewed on average 4.2 times $(\mathrm{N}=14,863)$. The dependent variable is the life satisfaction difference between husband and wife.

[Table 2 about here]

\footnotetext{
${ }^{8}$ We run a linear projection of the log of individual earnings on ten-year age cohorts, six different levels of schooling, controls for the number of sons and daughters ever had, as well as provincial and year fixed effects. Regressions are run separately for women and men. The results of the earnings regressions are displayed in Table A3 in the appendix.

${ }^{9}$ Figure A1 in the appendix gives a first intuition how predicted relative spousal earnings potential outside of marriage is related to wives' and husbands' life satisfaction. It supports the notion that monetary outside options matter for the intrahousehold allocation of experienced utility.

${ }^{10}$ The variables included are related to age, education, health, education and economic background of parents, province of residence, number of children, and year. The prediction coefficients are displayed in table A4 in the appendix.
} 


\section{IV.2.1 All couples}

Columns 1 and 4 show the results of using the log of actual earnings by spouse as potential factors to indicate the outside options of husband and wife. While the model in column 1 was estimated with OLS, column 4 reports (individual) fixed effects (FE) estimation results. Coefficients are, as expected, positive for men and negative for women. However, actual earnings have no clear statistically significant relationship with the dependent variable. Thus, for reasons mentioned earlier, actual labor supply does not provide the best approximation of threat point utility and is further likely to be endogenously determined.

In columns 2 and 5, predicted earnings are used in place of actual earnings. Our focus lies on FE results in column 5, our preferred specification, since OLS results in column 2 fail to account for individual unobserved heterogeneity. Coefficients indicate that while husbands' predicted earnings do not play a role, wives' predicted earnings are strongly associated with the contemporaneous distribution of experienced utility in the household. A doubling of potential female earnings leads to a rise in a wife's life satisfaction (relative to her husband's) by 0.262 units or by 41 percent of a standard deviation in female life satisfaction. These results are further confirmed if both actual earnings and predicted earnings are included alongside in the regression (columns 3 and 6). ${ }^{11}$

Other relevant variables in the distribution of relative spousal happiness are one's own and spousal health status, as well as the number of infants and old females living with the couple in the household.

Table A5 in the appendix reports the estimation of all equations (12) to (15) side-by-side. A few more interesting findings appear: While husbands and wives both value spousal health, own health status enters one's utility function two to three times as strong as spousal health. Moreover,

\footnotetext{
${ }^{11}$ Note that results also hold if prediction coefficients are derived from a sample of never married, instead of the sample of divorced, separated, and remarried used here. Results are not displayed for space reasons but are available from the authors upon request.
} 
women seem to care more about the relative income position of the household than men. Also, the duration of marriage is found to be negatively related to the gains from marriage.

\section{IV.2.2 Dual-earner couples}

Married women who are currently working might find it easier to provide for themselves in case of marital breakup. Thus, they might have a more preferable divorce threat as compared to homemakers (Bowlus and Seitz, 2006). In order to analyze this effect we restrict the sample to dual-earner couples in which case the number of observations falls from 14,863 to 5,274 , indicating the high prevalence of female homemakers in Korea.

[Table 3 about here]

Related results are presented in Table 3. We now see more significant coefficients for both actual and predicted earnings. Our preferred specification in column (5) shows the expected signs for predicted earnings of husband and wife. Table 2's results are confirmed and the effect of wives' predicted earnings even rises in size. A doubling in predicted earnings outside of marriage raises working wives' relative life satisfaction by 0.360 or 56 percent of a standard deviation in female life satisfaction.

Regression results in Tables 3 and 4 provide evidence for the important role of the out-ofmarriage earnings potential in determining the allocation of utility within married households. Interestingly, only women's potential earnings have the power to alter the relative distribution of happiness significantly.

IV.2.3 Excess utility in marriage 
In order to remain in a marital union, its benefits must at least outweigh its costs. The cost of remaining in a cooperative bargaining game is equal to the fallback position. Thus, there should be non-negative excess utility from marriage. Table 4 tests this assumption separately for younger and older couples. ${ }^{12}$ Indeed, average predicted threat point satisfaction is significantly lower than actual satisfaction experienced within marriage for both women and men, regardless of their age. Levels of excess satisfaction are all substantial in magnitudes and highly statistically significant.

Table 4 allows for a more detailed interpretation of the gains from marriage. Thus we might ask whether gains from marriage differ by gender or by age of the couple. Earlier literature has found that men gain more from marriage in Korea. In addition, younger couples are less likely to follow traditional gender role models. The first thing to note is that no significant gender differences exist in the levels of actual satisfaction/utility. Younger couples are moreover found to be on average happier than older couples. Regarding threat-point utility, we find that women show higher levels of satisfaction compared to men in the case of marital breakup. This gender gap in threat points is higher for older couples. Finally, excess utility/satisfaction is higher for married men within older couples. Male excess utility in these couples accounts for 0.411 or 65 percent of a standard deviation in male life satisfaction. Female excess utility accounts for only 0.346 or 54 percent of a standard deviation in female life satisfaction. While these gender differences may not appear very large, they are highly significant. Most interestingly, and in line with our expectations that younger couples share resources more equally, the gender difference in excess utility disappears for younger couples.

\section{[Table 4 about here]}

Our results in this subsection support the idea that marital arrangements are able to create some kind of gain that is shared among partners. This sharing, however, is not always equal. Within older Korean couples, men benefit more from marriage than women, i.e. they are able to extract more of the additionally created utility than their spouses. The exact pathway how this happens, however, remains unclear. One possible explanation could be based on Akerlof and Kranton's

\footnotetext{
${ }^{12}$ We define young couples as couples with wives of age 40 or younger. Older couples are those with wives older than 40 years of age. The threshold at age 40 is similar to Ham and Song (2014).
} 
(2000) theory of identity economics: married (unwed) men might benefit (suffer) from a direct utility gain (loss) that Korean society attaches to their respective identity. Since social norms and gender roles change over time, this could also explain why no such marital gender gap can be found for young couples. An alternative/ complimentary explanation might be that the gain stems from the provision of a public family good. For example, it could be the case that unwed Korean men have no or less access to the public family good. As a consequence, male threat point utility would be relatively low and gains from marriage relatively high.

Previous studies have shown that Korean husbands perceive higher levels of spousal support (both emotional and physical) than do wives (Kim and Jun, 1997; Seo and Kim, 2000). It has also been found that living alone is significantly associated with depressive symptoms and suicidal ideation in elderly Korean men but not in women (Jeon et al., 2007). In a follow-up study, Jang et al. (2009) recently showed that there are marked gender differences in the health benefits of marriage among older Koreans: unless most Western studies, being married in Korea reduces depressive symptoms mainly for men, but much less so for women. While the health benefits of marriage are consistently positive for men across all age groups, they are smaller in size for women and cease to be significant for the eldest cohort. Although not providing any causal explanation, the authors suggest that the distinctive influence of the East Asian context on relations between men and women, such as traditional gender roles and patriarchal norms, which are most prevalent among members of the older generation, are likely to drive their results. ${ }^{13}$

\section{IV.2.4 Sensitivity of results}

This section will examine the robustness of results from subsection IV.2.1 and related Table 2 to changes in the specification of our empirical model. Table 5 reports the results of various alterations that the researcher might find important to check. Baseline results are reported in column 1 and stem from our preferred specification (column 5 of Table 2).

\footnotetext{
${ }^{13}$ Note the consistency of findings across three major Korean data sets. While Jeon et al. (2007) use the 2001 Korean National Health and Nutrition Examination Survey, Jang et al. (2009) use the 2006 Korean Longitudinal Study of Ageing. Our results stem from the Korean Labor and Income Panel Study (2003-2008).
} 
In columns 2 to 5 we check for the robustness of results to changes in the prediction equations. So far, both husband and wife's prediction equations are mainly identified by an individual's return to education varying across provinces, years, age cohorts, and household composition (compare with Table A3 in the appendix).

Column 2 adds the variable 'diseases' to the prediction equation to account for the influence that good health plays to establish a credible divorce threat. This variable builds on detailed data from a one-time extended health module added to the general KLIPS questionnaire in 2003. Respondents were asked whether they have ever been diagnosed with a list of major diseases. Information on a total of 20 diseases is recorded including cancer, diabetes, gastritis, chronic bronchitis, etc. The variable 'diseases' is then constructed as a simple additive index counting the number of reported diagnosed and not cured diseases as of 2003. Adding 'diseases' improves the fit of both prediction equations and strengthens our earlier results. The coefficient for wives' predicted earnings rises (in absolute terms) from 0.262 to 0.321 .

[Table 5 about here]

Column 3 adds information on parental education to the prediction equations. Interestingly, only 'mother's schooling' is significant in first stage regressions. Mother's schooling is a proxy of wider family assets and networks that can improve an individual's outside options. This variable also strengthens the coefficient for wives' predicted earnings which rises to $|0.310|$.

Column 4 adds the variable 'perceived economic status' to the prediction equations. This variable was collected in 2002, but not in later waves of KLIPS. It asks respondents to rank themselves on a 6-item ladder of economic status ranging from 'lower-bottom' to 'upper highest'. This variable again adds significantly to the prediction equation as it adds additional information on household wealth. It leads to a strong increase in the wives' predicted earnings coefficient to |0.458|.

While the three additional variables discussed above tend to improve the prediction equations, they were not included from the beginning since this would have resulted in a significant drop in the estimation sample. 
In column 5, we changed the external sample used to estimate prediction coefficients for the out-of-marriage earnings potential. We substitute a sample of never married for the sample of separated, divorced, and remarried. Basic results are again confirmed, although only on a 10percent significance level ( $\mathrm{p}$-value=0.074).

Column 6 addresses the issue of reporting error. Some couples (in particular those running a family enterprise) might report equal earnings for wife and husband when being close to equal earnings. Thus, we can see some heaping behavior at a wife's share in earnings of 0.5. This phenomenon has been found earlier by other studies (see for example Bertrand et al., 2013). In order to check whether heaping affects our results, we drop all couples that report equal earnings shares. Again, our basic results are not affected $(|0.286|)$.

Finally, column 7 deals with the issue of potential endogeneity of health variables. Since both life satisfaction and health are self-reported, it might be the case that happier people tend to have a more positive evaluation of their overall health status. This would render the health variable endogenous. Thus, in column 7 we exclude the health variables from the main model. Once more, this does not affect our findings. The coefficient for wives' predicted earnings is in the same range as the baseline results $(|0.250|)$.

\section{Concluding remarks}

This article presents an empirical test of the standard bargaining theory of marriage in an economically and socially dynamic society. Using a direct measure of utility instead of revealed preferences, theoretical predictions are for the most part confirmed by empirical findings. Results provide evidence for substantial gains from marriage for both Korean women and men. Evidence suggests that the distribution of utility within a household is partly determined by a partner's relative threat point. In particular, we find that the higher a partner's relative predicted earnings outside of marriage, the higher her/ his relative gains from marriage. This finding has important policy implications. It implies that a better financial endowment of separated and divorced women will not only help in reducing the relatively high poverty prevalence of this particularly vulnerable group. It will also lead to more equitable and 'grown-up' marriages in Korea. A government 
interested in improving women's situations might achieve this via stricter rules and a faster legal enforcement of alimony payments as well as through an expansion of the earned income tax credit which is a promising and already existing policy tool whose potential however remains largely underused in Korea (OECD, 2013).

The analysis of this paper also revealed a gender asymmetry particularly within older couples which standard bargaining models are currently not able to incorporate. We find that Korean women are naturally endowed with a higher level of life satisfaction than men. Men are able to make up for this happiness deficit by having access to higher incomes, higher levels of schooling, and by enjoying, ceteris paribus, higher gains from marriage. This gender asymmetry is found to be stronger for older couples.

Although the causal channel remains unclear, one possible explanation for the asymmetry is that the answer lies within prescribed gender roles and related social norms which are likely to play a larger role than earlier thought by theoretical economists. Akerlof and Kranton (2000) argue in favor of including the concept of identity into neoclassical utility functions. Not acting in line with socially prescribed gender roles might be penalized by society, e.g. might exert a detrimental effect on one's personal utility. Agarwal (1997) argues that bargaining models usually fail to account for social norms, which themselves set limits on which issues can legitimately be bargained over and which fall in the realm of the uncontestable. These limits to bargaining may favor some groups over others, e.g. men over women. Apart from Lundberg and Pollak (1993), social norms are still largely absent in the bargaining literature. The fact that our findings indicate a higher gender asymmetry for older couples is in line with the phenomenon that gender identities are becoming more equal as countries develop over time. This would lend support to the approach by Akerlof and Kranton. However, the exact identification and quantification of the sources of the higher male utility gains from marriage are left for future work. 


\section{Acknowledgments}

We thank the Development Economics Research Group in Göttingen for valuable comments. The paper benefited further from fruitful discussions with Stephan Klasen, Inma Martinez-Zarzoso, Jinyoung Kim, Beomsoo Kim, Seik Kim, and Sung-jin Kang.

\section{References}

Agarwal, B. (1997). "Bargaining"and Gender Relations: Within and Beyond the Household. Feminist economics, 3(1), 1-51.

Akerlof, G. A., \& Kranton, R. E. (2000). Economics and identity. Quarterly Journal of Economics, 715-753.

Alesina, A., Di Tella, R., \& MacCulloch, R. (2004). Inequality and happiness: are Europeans and Americans different?. Journal of Public Economics, 88(9), 2009-2042.

Bertrand, M., Pan, J., \& Kamenica, E. (2013). Gender identity and relative income within households (No. w19023). National Bureau of Economic Research.

Bittman, M., England, P., Sayer, L., Folbre, N., \& Matheson, G. (2003). When Does Gender Trump Money? Bargaining and Time in Household Work1. American Journal of sociology, 109(1), 186-214.

Bowlus, A. J., \& Seitz, S. (2006). Domestic Violence, employment, and divorce. International Economic Review, 47(4), 1113-1149.

Brown, P. H. (2009). Dowry and Intrahousehold Bargaining Evidence from China. Journal of Human Resources, 44(1), 25-46.

Clark, A.E. and Oswald, A.J. (1994) Unhappiness and unemployment. The Economic Journal 104: 648-659.

Clark, A.E., Frijters, P. and Shields, M.A. (2008). Relative income, happiness, and utility: an explanation for the Easterlin Paradox and other puzzles. Journal of Economic Literature 46(1): 95-144.

Corra, M., Carter, S. K., Carter, J. S., \& Knox, D. (2009). Trends in marital happiness by gender and race, 1973 to 2006. Journal of Family Issues.

Deaton, A. (2008). Income, health and wellbeing around the world: evidence from the Gallup World Poll. Journal of Economic Perspectives 22(2): 53-72.

Dolan, P., Peasgood, T. and White, M. (2008). Do we really know what makes us happy? A review of the economic literature on the factors associated with subjective well-being. Journal of Economic Psychology 29: 94-122.

Doss, C. (2013). Intrahousehold bargaining and resource allocation in developing countries. The World Bank Research Observer, 28(1), 52-78. 
Duflo, E. (2003). Grandmothers and Granddaughters: Old-Age Pensions and Intrahousehold Allocation in South Africa. The World Bank Economic Review, 17(1), 1-25.

Easterlin, R.A. (1974) Does economic growth improve the human lot? Some empirical evidence. In P. David and M.W. Reder (Eds.), Nations and Households in Economic Growth: Essays in Honour of Moses Abramovitz (pp. 89-125). New York: Academic Press.

Ferrer-i-Carbonell, A., \& Frijters, P. (2004). How Important is Methodology for the estimates of the determinants of Happiness?*. The Economic Journal, 114(497), 641-659.

Gardner, J. and Oswald, A.J. (2007). Money and mental wellbeing: a longitudinal study of medium-sized lottery wins. Journal of Health Economics 26(1): 49-60.

Ham, J.C. and Song, H. (2014). The determinants of bargaining power in an empirical model of transfers between adult children, parents, and in-laws for South Korea. Journal of Development Economics 109(C): 73-86

Hoddinott, J., \& Haddad, L. (1995). Does female income share influence household expenditures? Evidence from Côte d'Ivoire. Oxford Bulletin of Economics and Statistics, 57(1), 77-96.

Jang, S. N., Kawachi, I., Chang, J., Boo, K., Shin, H. G., Lee, H., \& Cho, S. I. (2009). Marital status, gender, and depression: analysis of the baseline survey of the Korean Longitudinal Study of Ageing (KLoSA). Social science \& medicine, 69(11), 1608-1615.

Jeon, G. S., Jang, S. N., Rhee, S. J., Kawachi, I., \& Cho, S. I. (2007). Gender differences in correlates of mental health among elderly Koreans. The Journals of Gerontology Series B: Psychological Sciences and Social Sciences, 62(5), S323-S329.

Kahneman, D., Wakker, P.P. and Sarin, R. (1997) Back to Bentham? Explorations of experienced utility. Quarterly Journal of Economics 112(2): 375-405.

Kang, Sung-Jin. 2010. "The Analysis on the Determinants of Life Satisfaction in Korea." Kyongjehak Yongu 58(1): 5-36.

Kim, T. H. and G. Y. Jun (1997). A study on the conjugal support, the share of household activities and marital adjustment in old age. Journal of the Korea Gerontological Society, 17(2), 167-182, (in Korean).

Layard, R. (2010). Measuring subjective well-being. Science 327(5965): 534-535.

Li, L., \& Wu, X. (2011). Gender of children, bargaining power, and intrahousehold resource allocation in China. Journal of Human Resources, 46(2), 295-316.

Lundberg, Shelly and Pollak, Robert (1993): "Separate Spheres Bargaining and the Marriage Market", Journal of Political Economy, 101(6), 988-1010.

Lundberg, S. J., Pollak, R. A., \& Wales, T. J. (1997). Do husbands and wives pool their resources? Evidence from the United Kingdom child benefit. Journal of Human Resources, 463-480.

Luttmer, E.F.P. (2005) Neighbors as negatives: relative earnings and well-being. Quarterly Journal of Economics 120(3): 963-1002. 
Lykken, D., \& Tellegen, A. (1996). Happiness is a stochastic phenomenon. Psychological science, 7(3), 186-189.

Manser, Marilyn and Brown, Murray (1980): "Marriage and Household Decision Theory - A Bargaining Analysis" International Economic Review, 21, 21-34.

McElroy, Marjorie and Horney, Mary (1981): "Nash-Bargained Decisions: Toward a Generalization of the Theory of Demand" International Economic Review, 22, 333-349.

OECD (2013). Strengthening Social Cohesion in Korea. Assessment and Recommendations. OECD Publishing, Paris.

Rudolf, R. (2014). Work Shorter, Be Happier? Longitudinal Evidence from the Korean Five-Day Working Policy. Journal of Happiness Studies, 15(5), 1139-1163.

Rudolf, R. and S.-J. Kang (2015). Lags and Leads in Korean Life Satisfaction: When Gender Matters. Feminist Economics, 21(1).

Samuelson, P. A. (1954). The pure theory of public expenditure. The review of economics and statistics, 387-389.

Seo, B. S., and S. H. Kim (2000). A study on the marital satisfaction of elderly couple. Journal of the Korean Gerontological Society, 20(1), 55-67.

Stevenson, B., \& Wolfers, J. (2006). Bargaining in the shadow of the law: Divorce laws and family distress. The Quarterly Journal of Economics, 267-288.

Stiglitz, J.E., Sen, A. and Fitoussi, J.-P. (2009). Report by the Commission on The Measurement of Economic Performance and Social Progress.

Thomas, D. (1990). Intra-household resource allocation: An inferential approach. Journal of Human Resources, 635-664.

van Praag, B.M.S. and Ferrer-i-Carbonell, A. (2008). Happiness Quantified: A Satisfaction Calculus Approach (Revised edition). Oxford: Oxford University Press.

Weiss, Y. (1997). The formation and dissolution of families: Why marry? Who marries whom? And what happens upon divorce. Handbook of population and family economics, 1, 81123.

Yang, O. K. (2003). Quality of life across life domains: family structure and relations. Social Indicators Research, 62(1-3), 121-148.

Yoo, G. (2003). Women in the workplace: Gender and wage differentials. In: The Quality of Life in Korea (pp. 367-385). Springer Netherlands. 


\section{Tables and Figures}

Figure 1: Distribution of Utility in a Standard Bargaining Model

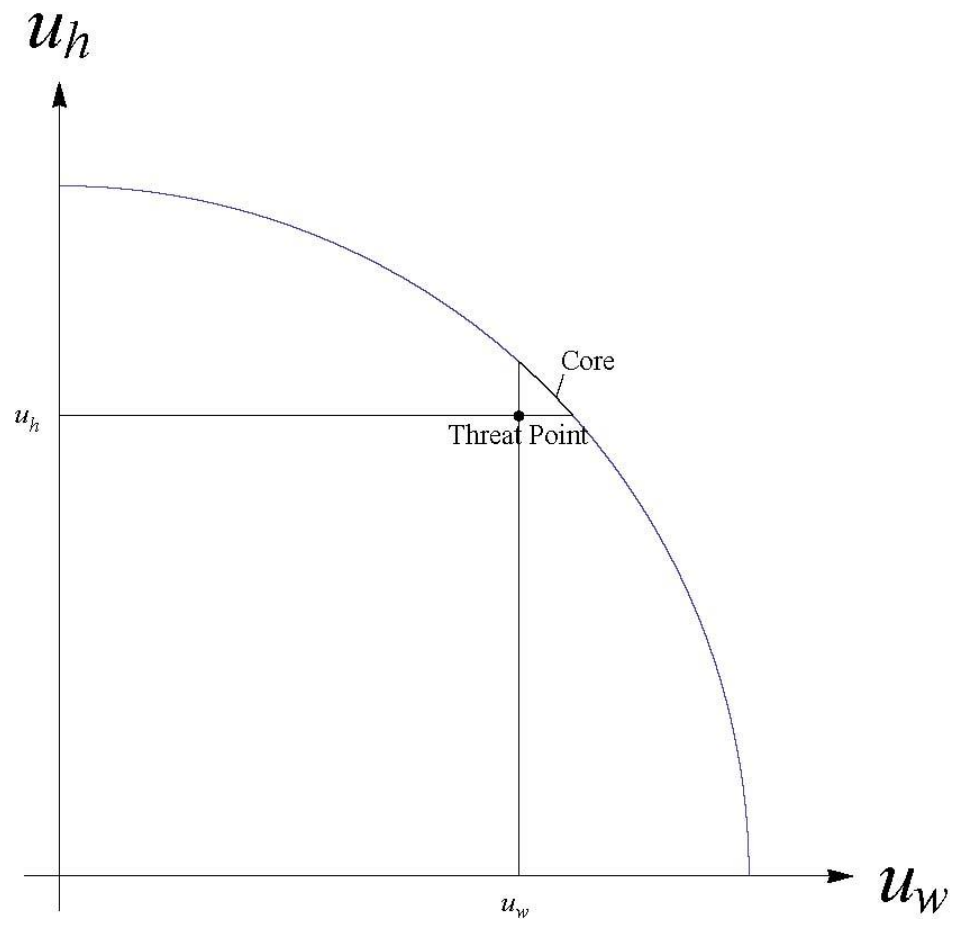

Figure 2: Wife's Share in Couple Earnings and Relative Spousal Happiness

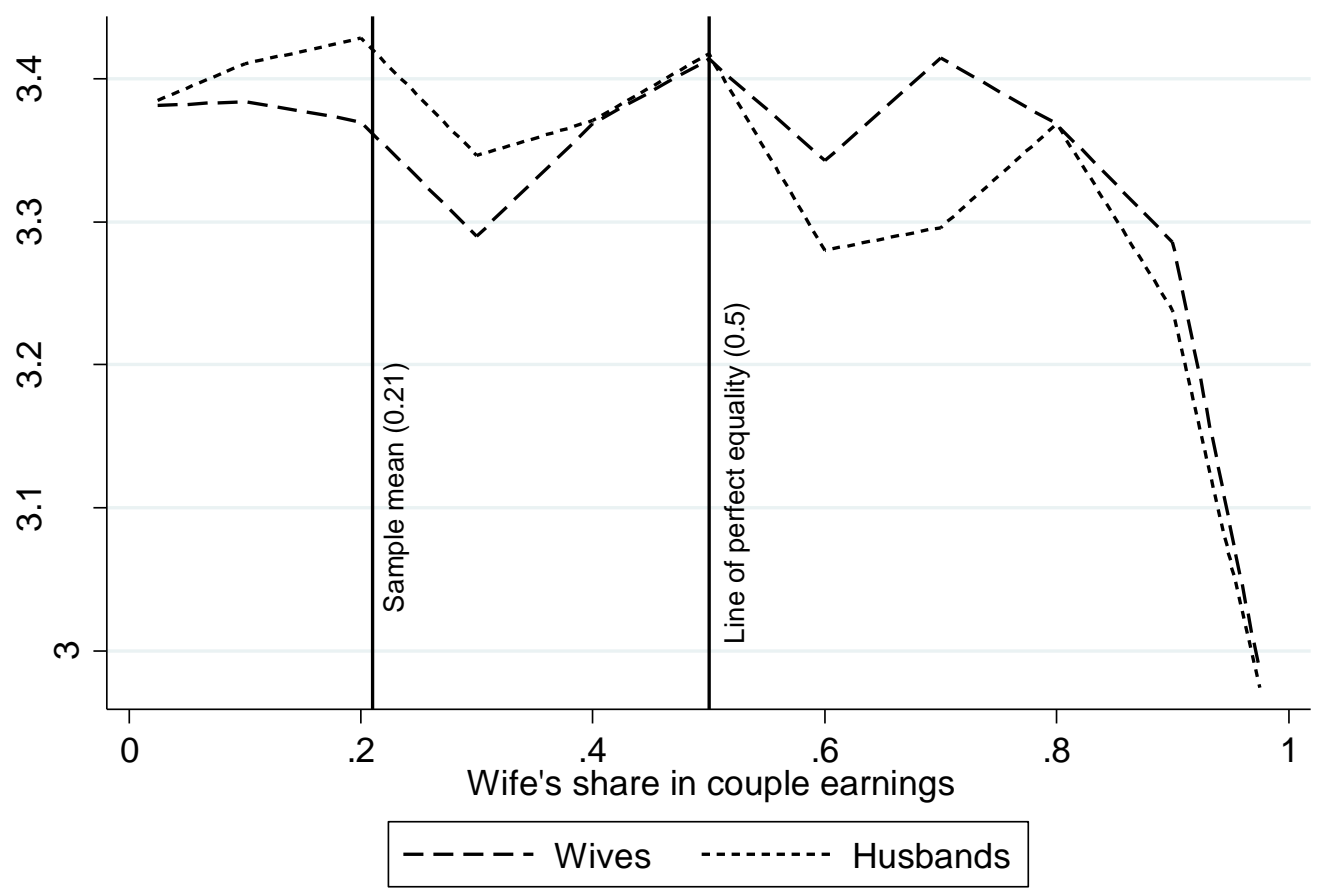


Table 1: Sex, Marriage, and Life Satisfaction in Korea

Dependent Variable: Life satisfaction

(1)

(2)

(3)

\begin{tabular}{l}
\hline-0.000319 \\
$(0.000837)$ \\
$-0.00004 * * *$ \\
$(9.23 \mathrm{e}-06)$ \\
0.00422 \\
$(0.00495)$
\end{tabular}

Married

Sex*Married

Years of schooling

Ln per-capita hh

income

Health

\begin{tabular}{lllllll} 
Age & -0.000319 & $-0.0229 * * *$ & $-0.0243^{* * *}$ & $-0.0306^{* * *}$ & $-0.0298^{* * *}$ & $-0.0261^{* * *}$ \\
& $(0.000837)$ & $(0.00103)$ & $(0.00102)$ & $(0.000992)$ & $(0.000986)$ & $(0.000961)$ \\
Age2 & $-0.00004 * * *$ & $0.00017^{* * *}$ & $0.00026^{* * *}$ & $0.00033^{* * *}$ & $0.00032^{* * *}$ & $0.00032^{* * *}$ \\
& $(9.23 \mathrm{e}-06)$ & $(1.10 \mathrm{e}-05)$ & $(1.09 \mathrm{e}-05)$ & $(1.07 \mathrm{e}-05)$ & $(1.06 \mathrm{e}-05)$ & $(1.03 \mathrm{e}-05)$ \\
Sex $(1=$ male) & 0.00422 & $-0.0334^{* * *}$ & $-0.129^{* * *}$ & $-0.137 * * *$ & $-0.138^{* * *}$ & $-0.166^{* * *}$ \\
& $(0.00495)$ & $(0.00835)$ & $(0.00824)$ & $(0.00802)$ & $(0.00798)$ & $(0.00779)$ \\
Married & & $0.0981^{* * *}$ & $0.0921^{* * *}$ & $0.0635^{* * *}$ & $0.0590^{* * *}$ & $0.0635^{* * *}$ \\
& & $(0.00717)$ & $(0.00698)$ & $(0.00682)$ & $(0.00678)$ & $(0.00663)$ \\
Sex*Married & & $0.0533^{* * *}$ & $0.101^{* * *}$ & $0.119^{* * *}$ & $0.118^{* * *}$ & $0.146^{* * *}$ \\
& & $(0.0103)$ & $(0.0101)$ & $(0.00980)$ & $(0.00974)$ & $(0.00951)$ \\
Years of schooling & & & $0.0386^{* * *}$ & $0.0279^{* * *}$ & $0.0294 * * *$ & $0.0166^{* * *}$ \\
& & & $(0.000638)$ & $(0.000652)$ & $(0.000650)$ & $(0.000672)$ \\
Ln per-capita hh & & & & $0.153^{* * *}$ & $0.155^{* * *}$ & $0.139 * * *$ \\
income & & & & $(0.00284)$ & $(0.00289)$ & $(0.00283)$ \\
Health & & & & & & $0.160^{* * *}$ \\
& & & & & & $(0.00320)$ \\
Province fixed effects & No & No & No & No & Yes & Yes \\
Year fixed effects & No & No & No & No & Yes & Yes \\
Constant & $3.248^{* * *}$ & $3.186^{* * *}$ & $2.771^{* * *}$ & $2.264 * * *$ & $2.148 * * *$ & $1.827 * * *$ \\
& $(0.00346)$ & $(0.00571)$ & $(0.00909)$ & $(0.0133)$ & $(0.0148)$ & $(0.0160)$ \\
\hline Observations & 66,537 & 66,537 & 66,537 & 66,537 & 66,537 & 66,537 \\
R-squared & 0.000 & 0.009 & 0.064 & 0.116 & 0.130 & 0.167 \\
\hline \hline
\end{tabular}

Notes: OLS estimation. KLIPS 2003-2008, full sample of ages 16-80. Robust standard errors in parentheses. *** $\mathrm{p}<0.01, * * \mathrm{p}<0.05$, * $\mathrm{p}<0.1$

(4)

(5)

(6) 
Table 2: Relative Spousal Earnings Potential

and Intrahousehold Happiness Allocation (all married couples)

Dependent variable: Life satisfaction difference (husband-wife)

\begin{tabular}{|c|c|c|c|c|c|c|}
\hline & (1) & $(2)$ & $(3)$ & (4) & $(5)$ & (6) \\
\hline & OLS & OLS & OLS & $\mathrm{FE}$ & $\mathrm{FE}$ & $\mathrm{FE}$ \\
\hline Ln earnings husband & $\begin{array}{l}0.00980 \\
(0.00706)\end{array}$ & & $\begin{array}{l}0.00878 \\
(0.00712)\end{array}$ & $\begin{array}{l}0.0101 \\
(0.00901)\end{array}$ & & $\begin{array}{l}0.0104 \\
(0.00901)\end{array}$ \\
\hline Ln earnings wife & $\begin{array}{l}-0.0157 * \\
(0.00905)\end{array}$ & & $\begin{array}{l}-0.0170 * \\
(0.00921)\end{array}$ & $\begin{array}{l}-0.00873 \\
(0.0128)\end{array}$ & & $\begin{array}{l}-0.00810 \\
(0.0128)\end{array}$ \\
\hline Ln predicted earnings husband & & $\begin{array}{l}0.0247 \\
(0.0243)\end{array}$ & $\begin{array}{l}0.0245 \\
(0.0245)\end{array}$ & & $\begin{array}{l}-0.0321 \\
(0.137)\end{array}$ & $\begin{array}{l}-0.0327 \\
(0.137)\end{array}$ \\
\hline Ln predicted earnings wife & & $\begin{array}{l}0.00162 \\
(0.0274)\end{array}$ & $\begin{array}{l}0.00528 \\
(0.0276)\end{array}$ & & $\begin{array}{l}-0.262 * * \\
(0.125)\end{array}$ & $\begin{array}{l}-0.263 * * \\
(0.125)\end{array}$ \\
\hline Ln per-capita hh income & $\begin{array}{l}-0.0110 \\
(0.00730)\end{array}$ & $\begin{array}{l}-0.0113 * \\
(0.00681)\end{array}$ & $\begin{array}{l}-0.0120 \\
(0.00739)\end{array}$ & $\begin{array}{l}-0.00252 \\
(0.00943)\end{array}$ & $\begin{array}{l}-0.00152 \\
(0.00935)\end{array}$ & $\begin{array}{l}-0.00259 \\
(0.00943)\end{array}$ \\
\hline $\begin{array}{l}\text { Ln per-capita hh income } \\
\text { (provincial average) }\end{array}$ & $\begin{array}{l}0.131 \\
(0.102)\end{array}$ & $\begin{array}{l}0.137 \\
(0.102)\end{array}$ & $\begin{array}{l}0.132 \\
(0.102)\end{array}$ & $\begin{array}{l}0.208 * \\
(0.110)\end{array}$ & $\begin{array}{l}0.215 * \\
(0.110)\end{array}$ & $\begin{array}{l}0.210 * \\
(0.110)\end{array}$ \\
\hline Duration of marriage & $\begin{array}{l}0.00145 \\
(0.00140)\end{array}$ & $\begin{array}{l}0.00170 \\
(0.00141)\end{array}$ & $\begin{array}{l}0.00166 \\
(0.00141)\end{array}$ & $\begin{array}{l}-0.0106 \\
(0.0525)\end{array}$ & $\begin{array}{l}-0.00952 \\
(0.0525)\end{array}$ & $\begin{array}{l}-0.0109 \\
(0.0525)\end{array}$ \\
\hline Health husband & $\begin{array}{l}0.0699 * * * \\
(0.00779)\end{array}$ & $\begin{array}{l}0.0696 * * * \\
(0.00780)\end{array}$ & $\begin{array}{l}0.0696 * * * \\
(0.00779)\end{array}$ & $\begin{array}{l}0.0821 * * * \\
(0.00950)\end{array}$ & $\begin{array}{l}0.0822 * * * \\
(0.00950)\end{array}$ & $\begin{array}{l}0.0823 * * * \\
(0.00950)\end{array}$ \\
\hline Health wife & $\begin{array}{l}-0.0586 * * * \\
(0.00766)\end{array}$ & $\begin{array}{l}-0.0590 * * * \\
(0.00768)\end{array}$ & $\begin{array}{l}-0.0588 * * * \\
(0.00768)\end{array}$ & $\begin{array}{l}-0.0680 * * * \\
(0.00939)\end{array}$ & $\begin{array}{l}-0.0680 * * * \\
(0.00939)\end{array}$ & $\begin{array}{l}-0.0680 * * * \\
(0.00939)\end{array}$ \\
\hline No of children aged $0-3$ years & $\begin{array}{l}0.0268 * * \\
(0.0135)\end{array}$ & $\begin{array}{l}0.0254 * \\
(0.0136)\end{array}$ & $\begin{array}{l}0.0256^{*} \\
(0.0136)\end{array}$ & $\begin{array}{l}0.0419 * * \\
(0.0205)\end{array}$ & $\begin{array}{l}0.0492 * * \\
(0.0210)\end{array}$ & $\begin{array}{l}0.0490 * * \\
(0.0210)\end{array}$ \\
\hline No of children aged 4-6 & $\begin{array}{l}0.00419 \\
(0.0133)\end{array}$ & $\begin{array}{l}0.00396 \\
(0.0133)\end{array}$ & $\begin{array}{l}0.00298 \\
(0.0133)\end{array}$ & $\begin{array}{l}0.0273 \\
(0.0221)\end{array}$ & $\begin{array}{l}0.0327 \\
(0.0224)\end{array}$ & $\begin{array}{l}0.0325 \\
(0.0224)\end{array}$ \\
\hline No of children aged 7-14 & $\begin{array}{l}-0.000265 \\
(0.00873)\end{array}$ & $\begin{array}{l}-0.000374 \\
(0.00877)\end{array}$ & $\begin{array}{l}-0.00150 \\
(0.00883)\end{array}$ & $\begin{array}{l}0.0141 \\
(0.0192)\end{array}$ & $\begin{array}{l}0.0182 \\
(0.0194)\end{array}$ & $\begin{array}{l}0.0179 \\
(0.0194)\end{array}$ \\
\hline No of children aged $15-30$ & $\begin{array}{l}0.0194 * * \\
(0.00887)\end{array}$ & $\begin{array}{l}0.0199 * * \\
(0.00886)\end{array}$ & $\begin{array}{l}0.0186 * * \\
(0.00892)\end{array}$ & $\begin{array}{l}0.0129 \\
(0.0143)\end{array}$ & $\begin{array}{l}0.0148 \\
(0.0143)\end{array}$ & $\begin{array}{l}0.0145 \\
(0.0143)\end{array}$ \\
\hline No of old females in hh & $\begin{array}{l}-0.00421 \\
(0.0198)\end{array}$ & $\begin{array}{l}-0.00645 \\
(0.0198)\end{array}$ & $\begin{array}{l}-0.00443 \\
(0.0198)\end{array}$ & $\begin{array}{l}-0.157 * * * \\
(0.0561)\end{array}$ & $\begin{array}{l}-0.157 * * * \\
(0.0561)\end{array}$ & $\begin{array}{l}-0.158 * * * \\
(0.0561)\end{array}$ \\
\hline No of old males in hh & $\begin{array}{l}0.0143 \\
(0.0331)\end{array}$ & $\begin{array}{l}0.0136 \\
(0.0331)\end{array}$ & $\begin{array}{l}0.0145 \\
(0.0331)\end{array}$ & $\begin{array}{l}-0.0515 \\
(0.0808)\end{array}$ & $\begin{array}{l}-0.0502 \\
(0.0808)\end{array}$ & $\begin{array}{l}-0.0516 \\
(0.0808)\end{array}$ \\
\hline Own house & $\begin{array}{l}-0.00102 \\
(0.0108)\end{array}$ & $\begin{array}{l}-0.00105 \\
(0.0108)\end{array}$ & $\begin{array}{l}-0.00150 \\
(0.0108)\end{array}$ & $\begin{array}{l}-0.0191 \\
(0.0203)\end{array}$ & $\begin{array}{l}-0.0182 \\
(0.0203)\end{array}$ & $\begin{array}{l}-0.0182 \\
(0.0203)\end{array}$ \\
\hline 2004 & $\begin{array}{l}-0.00483 \\
(0.0177)\end{array}$ & $\begin{array}{l}-0.00744 \\
(0.0180)\end{array}$ & $\begin{array}{l}-0.00689 \\
(0.0180)\end{array}$ & $\begin{array}{l}0.000612 \\
(0.0552)\end{array}$ & $\begin{array}{l}-0.0113 \\
(0.0571)\end{array}$ & $\begin{array}{l}-0.00947 \\
(0.0571)\end{array}$ \\
\hline 2005 & $\begin{array}{l}-0.0259 \\
(0.0183)\end{array}$ & $\begin{array}{l}-0.0267 \\
(0.0183)\end{array}$ & $\begin{array}{l}-0.0265 \\
(0.0183)\end{array}$ & $\begin{array}{c}-0.0146 \\
(0.103)\end{array}$ & $\begin{array}{c}-0.0197 \\
(0.103)\end{array}$ & $\begin{array}{l}-0.0168 \\
(0.103)\end{array}$ \\
\hline 2006 & $\begin{array}{l}-0.0182 \\
(0.0255)\end{array}$ & $\begin{array}{l}-0.0225 \\
(0.0257)\end{array}$ & $\begin{array}{l}-0.0213 \\
(0.0257)\end{array}$ & $\begin{array}{l}-0.00420 \\
(0.158)\end{array}$ & $\begin{array}{l}0.00846 \\
(0.159)\end{array}$ & $\begin{array}{l}0.0139 \\
(0.159)\end{array}$ \\
\hline 2007 & $\begin{array}{l}-0.0299 \\
(0.0299)\end{array}$ & $\begin{array}{l}-0.0332 \\
(0.0300)\end{array}$ & $\begin{array}{l}-0.0321 \\
(0.0300)\end{array}$ & $\begin{array}{l}-0.00959 \\
(0.209)\end{array}$ & $\begin{array}{l}-0.00240 \\
(0.209)\end{array}$ & $\begin{array}{l}0.00451 \\
(0.209)\end{array}$ \\
\hline
\end{tabular}




\begin{tabular}{lllllll}
2008 & -0.0140 & -0.0187 & -0.0183 & 0.0213 & 0.0486 & 0.0568 \\
& $(0.0279)$ & $(0.0282)$ & $(0.0281)$ & $(0.265)$ & $(0.266)$ & $(0.267)$ \\
Constant & -0.597 & -0.777 & -0.733 & -0.930 & 0.474 & 0.513 \\
& $(0.467)$ & $(0.486)$ & $(0.486)$ & $(0.927)$ & $(1.286)$ & $(1.287)$ \\
\hline Couple observations & 14,863 & 14,863 & 14,863 & 14,863 & 14,863 & 14,863 \\
No of couples & 3,542 & 3,542 & 3,542 & 3,542 & 3,542 & 3,542 \\
\hline \hline
\end{tabular}

Notes: Robust standard errors in parentheses. $* * * \mathrm{p}<0.01, * * \mathrm{p}<0.05, * \mathrm{p}<0.1$. Control variables include a set of 10-year age cohort dummies, 14 provincial dummies, and 6 dummies each to account for main occupation of husband and wife during the last week. 


\section{Table 3: Relative Spousal Earnings Potential}

and Intrahousehold Happiness Allocation (dual-earner married couples)

Dependent variable: Life satisfaction difference (husband-wife)

\begin{tabular}{|c|c|c|c|c|c|c|}
\hline & (1) & (2) & (3) & (4) & (5) & (6) \\
\hline & OLS & OLS & OLS & FE & FE & FE \\
\hline Ln earnings husband & $\begin{array}{l}0.0454 * * * \\
(0.0176)\end{array}$ & & $\begin{array}{l}0.0418 * * \\
(0.0180)\end{array}$ & $\begin{array}{l}0.0809 * * \\
(0.0326)\end{array}$ & & $\begin{array}{l}0.0813 * * \\
(0.0327)\end{array}$ \\
\hline Ln earnings wife & $\begin{array}{l}-0.0308 * * \\
(0.0150)\end{array}$ & & $\begin{array}{l}-0.0319 * * \\
(0.0158)\end{array}$ & $\begin{array}{l}-0.0126 \\
(0.0325)\end{array}$ & & $\begin{array}{l}-0.0119 \\
(0.0325)\end{array}$ \\
\hline $\begin{array}{l}\text { Ln predicted earnings husband } \\
\text { (threat) }\end{array}$ & & $\begin{array}{l}0.0806 * * \\
(0.0397)\end{array}$ & $\begin{array}{l}0.0751 * \\
(0.0410)\end{array}$ & & $\begin{array}{l}0.110 \\
(0.228)\end{array}$ & $\begin{array}{l}0.0873 \\
(0.228)\end{array}$ \\
\hline $\begin{array}{l}\text { Ln predicted earnings wife } \\
\text { (threat) }\end{array}$ & & $\begin{array}{l}-0.0591 \\
(0.0417)\end{array}$ & $\begin{array}{l}-0.0511 \\
(0.0427)\end{array}$ & & $\begin{array}{l}-0.360 * * \\
(0.176)\end{array}$ & $\begin{array}{l}-0.364 * * \\
(0.175)\end{array}$ \\
\hline Ln per-capita hh income & $\begin{array}{l}-0.0155 \\
(0.0155)\end{array}$ & $\begin{array}{l}-0.0116 \\
(0.0130)\end{array}$ & $\begin{array}{l}-0.0154 \\
(0.0154)\end{array}$ & $\begin{array}{l}-0.0193 \\
(0.0227)\end{array}$ & $\begin{array}{l}-0.00560 \\
(0.0216)\end{array}$ & $\begin{array}{l}-0.0187 \\
(0.0227)\end{array}$ \\
\hline $\begin{array}{l}\text { Ln per-capita hh income } \\
\text { (provincial average) }\end{array}$ & $\begin{array}{l}0.0330 \\
(0.171)\end{array}$ & $\begin{array}{l}0.0488 \\
(0.170)\end{array}$ & $\begin{array}{l}0.0324 \\
(0.170)\end{array}$ & $\begin{array}{l}0.288 \\
(0.194)\end{array}$ & $\begin{array}{l}0.308 \\
(0.194)\end{array}$ & $\begin{array}{l}0.292 \\
(0.194)\end{array}$ \\
\hline Duration of marriage & $\begin{array}{l}0.00376 \\
(0.00240)\end{array}$ & $\begin{array}{l}0.00378 \\
(0.00242)\end{array}$ & $\begin{array}{l}0.00385 \\
(0.00242)\end{array}$ & $\begin{array}{l}-0.0572 \\
(0.0939)\end{array}$ & $\begin{array}{l}-0.0546 \\
(0.0939)\end{array}$ & $\begin{array}{l}-0.0580 \\
(0.0939)\end{array}$ \\
\hline Health husband & $\begin{array}{l}0.0927 * * * \\
(0.0130)\end{array}$ & $\begin{array}{l}0.0951 * * * \\
(0.0130)\end{array}$ & $\begin{array}{l}0.0928 * * * \\
(0.0130)\end{array}$ & $\begin{array}{l}0.0938 * * * \\
(0.0169)\end{array}$ & $\begin{array}{l}0.0968 * * * \\
(0.0169)\end{array}$ & $\begin{array}{l}0.0944 * * * \\
(0.0169)\end{array}$ \\
\hline Health wife & $\begin{array}{l}-0.0857 * * * \\
(0.0136)\end{array}$ & $\begin{array}{l}-0.0865 * * * \\
(0.0136)\end{array}$ & $\begin{array}{l}-0.0862 * * * \\
(0.0136)\end{array}$ & $\begin{array}{l}-0.0895 * * * \\
(0.0174)\end{array}$ & $\begin{array}{l}-0.0903 * * * \\
(0.0174)\end{array}$ & $\begin{array}{l}-0.0897 * * * \\
(0.0174)\end{array}$ \\
\hline No of children aged $0-3$ years & $\begin{array}{l}0.00770 \\
(0.0239)\end{array}$ & $\begin{array}{l}0.00708 \\
(0.0243)\end{array}$ & $\begin{array}{l}0.00770 \\
(0.0243)\end{array}$ & $\begin{array}{l}0.0463 \\
(0.0417)\end{array}$ & $\begin{array}{l}0.0540 \\
(0.0422)\end{array}$ & $\begin{array}{l}0.0522 \\
(0.0422)\end{array}$ \\
\hline No of children aged 4-6 & $\begin{array}{l}0.00219 \\
(0.0235)\end{array}$ & $\begin{array}{l}0.00231 \\
(0.0237)\end{array}$ & $\begin{array}{l}-0.000498 \\
(0.0237)\end{array}$ & $\begin{array}{l}0.0393 \\
(0.0432)\end{array}$ & $\begin{array}{l}0.0444 \\
(0.0435)\end{array}$ & $\begin{array}{l}0.0436 \\
(0.0435)\end{array}$ \\
\hline No of children aged 7-14 & $\begin{array}{l}0.00227 \\
(0.0144)\end{array}$ & $\begin{array}{l}0.00650 \\
(0.0144)\end{array}$ & $\begin{array}{l}0.000871 \\
(0.0146)\end{array}$ & $\begin{array}{l}0.0693 * * \\
(0.0339)\end{array}$ & $\begin{array}{l}0.0744 * * \\
(0.0341)\end{array}$ & $\begin{array}{l}0.0733 * * \\
(0.0341)\end{array}$ \\
\hline No of children aged $15-30$ & $\begin{array}{l}0.0217 \\
(0.0146)\end{array}$ & $\begin{array}{l}0.0264 * \\
(0.0144)\end{array}$ & $\begin{array}{l}0.0212 \\
(0.0146)\end{array}$ & $\begin{array}{l}0.0431 * \\
(0.0250)\end{array}$ & $\begin{array}{l}0.0460 * \\
(0.0251)\end{array}$ & $\begin{array}{l}0.0448 * \\
(0.0251)\end{array}$ \\
\hline No of old females in hh & $\begin{array}{l}-0.0178 \\
(0.0292)\end{array}$ & $\begin{array}{l}-0.0216 \\
(0.0291)\end{array}$ & $\begin{array}{l}-0.0169 \\
(0.0292)\end{array}$ & $\begin{array}{l}-0.167 * \\
(0.0971)\end{array}$ & $\begin{array}{l}-0.169 * \\
(0.0972)\end{array}$ & $\begin{array}{l}-0.170 * \\
(0.0971)\end{array}$ \\
\hline No of old males in hh & $\begin{array}{l}-0.0370 \\
(0.0491)\end{array}$ & $\begin{array}{l}-0.0448 \\
(0.0495)\end{array}$ & $\begin{array}{l}-0.0392 \\
(0.0492)\end{array}$ & $\begin{array}{l}-0.0787 \\
(0.150)\end{array}$ & $\begin{array}{l}-0.0850 \\
(0.150)\end{array}$ & $\begin{array}{l}-0.0837 \\
(0.150)\end{array}$ \\
\hline Own house & $\begin{array}{l}0.0276 \\
(0.0172)\end{array}$ & $\begin{array}{l}0.0306 * \\
(0.0172)\end{array}$ & $\begin{array}{l}0.0277 \\
(0.0172)\end{array}$ & $\begin{array}{l}-0.0359 \\
(0.0350)\end{array}$ & $\begin{array}{l}-0.0334 \\
(0.0351)\end{array}$ & $\begin{array}{l}-0.0347 \\
(0.0351)\end{array}$ \\
\hline 2004 & $\begin{array}{l}0.0362 \\
(0.0299)\end{array}$ & $\begin{array}{l}0.0263 \\
(0.0303)\end{array}$ & $\begin{array}{l}0.0273 \\
(0.0303)\end{array}$ & $\begin{array}{l}0.0697 \\
(0.0992)\end{array}$ & $\begin{array}{l}0.0396 \\
(0.102)\end{array}$ & $\begin{array}{l}0.0442 \\
(0.102)\end{array}$ \\
\hline 2005 & $\begin{array}{l}0.0153 \\
(0.0306)\end{array}$ & $\begin{array}{l}0.0115 \\
(0.0306)\end{array}$ & $\begin{array}{l}0.0133 \\
(0.0306)\end{array}$ & $\begin{array}{l}0.0943 \\
(0.185)\end{array}$ & $\begin{array}{l}0.0824 \\
(0.186)\end{array}$ & $\begin{array}{l}0.0889 \\
(0.185)\end{array}$ \\
\hline 2006 & $\begin{array}{l}-0.00472 \\
(0.0429)\end{array}$ & $\begin{array}{l}-0.0133 \\
(0.0431)\end{array}$ & $\begin{array}{l}-0.00988 \\
(0.0432)\end{array}$ & $\begin{array}{l}0.132 \\
(0.284)\end{array}$ & $\begin{array}{l}0.130 \\
(0.285)\end{array}$ & $\begin{array}{l}0.144 \\
(0.285)\end{array}$ \\
\hline 2007 & $\begin{array}{l}0.0256 \\
(0.0502)\end{array}$ & $\begin{array}{l}0.0200 \\
(0.0502)\end{array}$ & $\begin{array}{l}0.0227 \\
(0.0503)\end{array}$ & $\begin{array}{l}0.188 \\
(0.375)\end{array}$ & $\begin{array}{l}0.183 \\
(0.375)\end{array}$ & $\begin{array}{l}0.199 \\
(0.375)\end{array}$ \\
\hline
\end{tabular}




\begin{tabular}{lllllll}
2008 & -0.00915 & -0.0157 & -0.0135 & 0.264 & 0.275 & 0.297 \\
& $(0.0465)$ & $(0.0471)$ & $(0.0472)$ & $(0.479)$ & $(0.480)$ & $(0.480)$ \\
Constant & -0.273 & -0.400 & -0.371 & -0.902 & 0.450 & 0.415 \\
& $(0.781)$ & $(0.810)$ & $(0.811)$ & $(1.601)$ & $(2.105)$ & $(2.106)$ \\
\hline Couple observations & 5,274 & 5,274 & 5,274 & 5,274 & 5,274 & 5,274 \\
No of couples & 1,740 & 1,740 & 1,740 & 1,740 & 1,740 & 1,740 \\
\hline \hline
\end{tabular}

Notes: Robust standard errors in parentheses. $* * * \mathrm{p}<0.01, * * \mathrm{p}<0.05, * \mathrm{p}<0.1$. Control variables include a set of 10 -year age cohort dummies and 14 provincial dummies.

Table 4: Excess Utility by Age of Couple

\begin{tabular}{|c|c|c|c|c|c|}
\hline & & $\begin{array}{l}\text { Actual } \\
\text { satisfaction }\end{array}$ & $\begin{array}{l}\text { Threat point } \\
\text { satisfaction }\end{array}$ & $\begin{array}{l}\text { Excess } \\
\text { satisfaction }\end{array}$ & $\operatorname{corr}(A, B)$ \\
\hline & & $\mathrm{A}$ & $\mathrm{B}$ & A-B & \\
\hline & & $\begin{array}{l}\text { Mean } \\
\text { (Std. Dev.) }\end{array}$ & $\begin{array}{l}\text { Mean } \\
\text { (Std. Dev.) }\end{array}$ & $\begin{array}{l}\text { Mean } \\
\text { (S.E.) }\end{array}$ & \\
\hline \multirow{3}{*}{$\begin{array}{c}\text { Older couples } \\
\text { (wife's age > 40; } \\
\quad \mathrm{N}=5,358)\end{array}$} & & $\begin{array}{l}3.329 \\
(0.609)\end{array}$ & $\begin{array}{l}2.918 \\
(0.332)\end{array}$ & $\begin{array}{l}0.411 * * * \\
(0.008)\end{array}$ & 0.328 \\
\hline & Wives & $\begin{array}{l}3.319 \\
(0.621)\end{array}$ & $\begin{array}{l}2.973 \\
(0.256)\end{array}$ & $\begin{array}{l}0.346^{* * * *} \\
(0.008)\end{array}$ & 0.227 \\
\hline & $\begin{array}{l}\text { Difference }(\mathrm{H}-\mathrm{W}) \\
\text { (S.E.) }\end{array}$ & $\begin{array}{l}0.010 \\
(0.008)\end{array}$ & $\begin{array}{l}-0.055^{* * *} \\
(0.005)\end{array}$ & $\begin{array}{l}0.065 * * * \\
(0.009) \\
\end{array}$ & \\
\hline \multirow{5}{*}{$\begin{array}{l}\text { Younger couples } \\
\text { (wife's age } \leq 40 ; \\
\quad \mathrm{N}=4,757 \text { ) }\end{array}$} & Husbands & 3.403 & 3.020 & $0.384 * * *$ & 0.262 \\
\hline & & $(0.601)$ & $(0.301)$ & $(0.009)$ & \\
\hline & Wives & $\begin{array}{l}3.412 \\
(0.608)\end{array}$ & $\begin{array}{l}3.037 \\
(0.251)\end{array}$ & $\begin{array}{l}0.375^{* * *} \\
(0.009)\end{array}$ & 0.258 \\
\hline & Difference $(\mathrm{H}-\mathrm{W})$ & -0.009 & $-0.017 * * *$ & 0.008 & \\
\hline & (S.E.) & $(0.009)$ & $(0.004)$ & $(0.009)$ & \\
\hline
\end{tabular}

Note: $* * * p<0.01, * * p<0.05, * p<0.1$. 
Table 5: Sensitivity Checks

Dependent variable: Life satisfaction difference (husband-wife)

\begin{tabular}{|c|c|c|c|c|c|c|c|}
\hline & $\begin{array}{l}(1) \\
\text { Baseline }\end{array}$ & $\begin{array}{l}(2) \\
\text { Augmented } \\
\text { prediction } \\
\text { equation I } \\
\text { (diseases) }\end{array}$ & $\begin{array}{l}\text { (3) } \\
\text { Augmented } \\
\text { prediction } \\
\text { equation II } \\
\text { (schoolmoth, } \\
\text { schoolfath) }\end{array}$ & $\begin{array}{l}\text { (4) } \\
\text { Augmented } \\
\text { prediction } \\
\text { equation III } \\
\text { (perceived } \\
\text { econ status) }\end{array}$ & $\begin{array}{l}\text { (5) } \\
\text { Never married } \\
\text { sample for } \\
\text { prediction } \\
\text { equation }\end{array}$ & $\begin{array}{l}(6) \\
\text { Drop if } \\
\text { wife's share } \\
\text { in earnings } \\
\text { is exactly half }\end{array}$ & $\begin{array}{l}(7) \\
\text { Drop } \\
\text { health } \\
\text { variables }\end{array}$ \\
\hline Ln predicted earnings husband & $\begin{array}{l}-0.0321 \\
(0.137)\end{array}$ & $\begin{array}{l}-0.00555 \\
(0.163)\end{array}$ & $\begin{array}{l}0.129 \\
(0.145)\end{array}$ & $\begin{array}{l}0.0218 \\
(0.175)\end{array}$ & $\begin{array}{l}0.101 \\
(0.171)\end{array}$ & $\begin{array}{l}-0.0790 \\
(0.141)\end{array}$ & $\begin{array}{l}-0.0503 \\
(0.138)\end{array}$ \\
\hline Ln predicted earnings wife & $\begin{array}{l}-0.262 * * \\
(0.125)\end{array}$ & $\begin{array}{l}-0.321 * * \\
(0.138)\end{array}$ & $\begin{array}{l}-0.310 * * \\
(0.127)\end{array}$ & $\begin{array}{l}-0.458^{* * *} \\
(0.171)\end{array}$ & $\begin{array}{c}-0.305^{*} \\
(0.171) \\
\end{array}$ & $\begin{array}{l}-0.286^{* *} \\
(0.127)\end{array}$ & $\begin{array}{l}-0.250 * * \\
(0.125)\end{array}$ \\
\hline $\begin{array}{l}\text { diseases (t-value in female pred equ) } \\
\text { diseases (t-value in male pred equ) } \\
\text { schoolmoth (t-value in female pred equ) } \\
\text { schoolfath (t-value in female pred equ) } \\
\text { schoolmoth (t-value in male pred equ) } \\
\text { schoolfath (t-value in male pred equ) } \\
\text { econstatus (t-value in female pred equ) } \\
\text { econstatus (t-value in male pred equ) }\end{array}$ & & $\begin{array}{l}-4.04 * * * \\
-4.49 * * *\end{array}$ & $\begin{array}{l}3.20 * * * \\
-1.07 \\
2.74 * * * \\
-0.05\end{array}$ & $\begin{array}{l}-4.74 * * * \\
-3.50 * * * \\
\end{array}$ & & & \\
\hline Couple observations & 14,863 & 12,514 & 11,122 & 11,218 & 14,863 & 14,557 & 14,863 \\
\hline No of couples & 3,542 & 2,708 & 2,544 & 2,419 & 3,542 & 3,530 & 3,542 \\
\hline
\end{tabular}

Note: Baseline results from Table 2, column 5 . All estimations are linear fixed effects models identical with the baseline specification except for the one alteration indicated above. Standard errors in parentheses. $* \mathrm{p}<.1 ; * * \mathrm{p}<.05 ; * * * \mathrm{p}<.01$ 


\section{Appendix}

Table A1: Distribution of Life Satisfaction by Sex

\begin{tabular}{lcccccc}
\hline \hline & \multicolumn{2}{c}{ Females } & & \multicolumn{2}{c}{ Males } \\
& \# of obs & Percentage & & \# of obs & Percentage \\
\cline { 2 - 3 } \cline { 6 - 7 } 1 (very dissatisfied) & 187 & 0.5 & & 192 & 0.6 \\
2 (dissatisfied) & 3,069 & 8.9 & & 2,726 & 8.4 \\
3 (neither satisfied nor dissatisfied) & 19,400 & 56.3 & & 18,382 & 56.7 \\
4 (satisfied) & 11,609 & 33.7 & & 10,955 & 33.8 \\
5 (very satisfied) & 210 & 0.6 & & 181 & 0.6 \\
\cline { 1 - 2 } Total & 34,475 & 100 & & 32,436 & 100 \\
Mean & 3.249 & & & 3.253 & \\
S.D. & 0.640 & & & 0.635 & \\
\hline \hline
\end{tabular}

Note: KLIPS 2003-2008. Ages 16-80. Means test of equality of female and male distributions: $t=-0.805$. 
Table A2: Description of Variables

\begin{tabular}{|c|c|c|c|c|c|}
\hline Variable & Description & \multicolumn{2}{|c|}{ Wives } & \multicolumn{2}{|c|}{ Husbands } \\
\hline $\begin{array}{l}\text { Individual } \\
\text { characteristics }\end{array}$ & & Mean & S.D. & Mean & S.D. \\
\hline Life satisfaction & Overall life satisfaction; scale from 1 (very dissatisfied) to 5 (very satisfied) & 3.34 & 0.62 & 3.35 & 0.61 \\
\hline Age & Age in years (in models 5-year age cohort dummies used) & 41.55 & 9.42 & 44.62 & 9.78 \\
\hline Schooling & Years of schooling & 11.84 & 3.08 & 12.83 & 3.08 \\
\hline Ln earnings & Log real monthly labor earnings & 2.00 & 2.42 & 4.77 & 1.89 \\
\hline Ln predicted earnings & Log real monthly labor earnings potential in case of marital breakup & 4.87 & 0.33 & 5.24 & 0.34 \\
\hline Econstatus & Perceived economic status (2002); scale from 1 (upper-highest) to 6 (lower-bottom) & 3.61 & 0.75 & 3.63 & 0.75 \\
\hline Health & Current health condition; scale from 1 (very poor) to 5 (excellent) & 3.47 & 0.76 & 3.55 & 0.76 \\
\hline Diseases & Count of 20 individual diseases ever diagnosed and not healed yet. Range from 0 to 20 . & 0.27 & 0.68 & 0.27 & 0.61 \\
\hline Schooling mother & Years of schooling of respondent's mother & 4.77 & 4.25 & 4.24 & 4.23 \\
\hline Schooling father & Years of schooling of respondent's father & 7.51 & 4.80 & 7.08 & 4.96 \\
\hline Econ. sit. at age 14 & $\begin{array}{l}\text { Family's economic situation when respondent was } 14 \text { years old; scale from } 1 \text { (much worse than } \\
\text { average) to } 5 \text { (much better than average) }\end{array}$ & 3.28 & 0.86 & 3.39 & 0.94 \\
\hline \multicolumn{6}{|c|}{ Occupation (main activity during last week) } \\
\hline Working & "Worked" or "Temporarily away from work" & 0.411 & 0.49 & 0.874 & 0.33 \\
\hline Homemaker & $\begin{array}{l}\text { "Looked after family or home/child caring or preparation for marriage"AND "did not have a } \\
\text { job last week" }\end{array}$ & 0.563 & 0.50 & 0.005 & 0.07 \\
\hline Retired & "Retired" or "old age" & 0.002 & 0.04 & 0.017 & 0.13 \\
\hline Illness & "Mental/physical illness" & 0.004 & 0.06 & 0.019 & 0.14 \\
\hline In education & Attended school, private academic institutes, or prepared for higher education & 0.002 & 0.04 & 0.002 & 0.04 \\
\hline Unemployed & "Searched for a job" AND "was able to work (if there was a suitable position) last week" & 0.008 & 0.09 & 0.025 & 0.16 \\
\hline Other occupation & All other occupations, reference category in Table A3 & 0.014 & 0.12 & 0.063 & 0.24 \\
\hline $\begin{array}{l}\text { Household } \\
\text { characteristics }\end{array}$ & & & Mean & S.D. & \\
\hline Duration of marriage & Number of years since couple married & & 16.86 & 10.69 & \\
\hline No of child $0-3$ & Number of children of respective couple aged 0 to 3 and living in the household & & 0.21 & 0.46 & \\
\hline No of child 4-6 & Number of children of respective couple aged 4 to 6 and living in the household & & 0.18 & 0.43 & \\
\hline No of child 7-14 & Number of children of respective couple aged 7 to 14 and living in the household & & 0.46 & 0.75 & \\
\hline
\end{tabular}


No of child 15-30

No of sons ever

No of daughters ever

No of old females

No of old males

Ln per-capita hh income

Own house

\section{Regional variables}

Provincial dummies

Ln per-capita hh income

(provincial average)

\section{Other variables}

Year dummies
Number of children of respective couple aged 15 to 30 , economically dependent and living in the household

Number of sons ever born or adopted

Number of daughters ever born or adopted

$0.89 \quad 0.86$

Number of females 65 years and older in the household

$0.07 \quad 0.26$

Number of males 65 years and older in the household

$0.02 \quad 0.15$

Log real monthly household income (in KRW10,000 of 2010) divided by household size;

$4.39 \quad 0.82$ provincial CPIs used.

Household is living in own house

0.63

0.48

Dummies of residence for all 15 major provinces except for the island of Jeju (not sampled)

Log average per-capita hh income (see above) by province; controls for relative income effects

Note: Summary statistics calculated for married sample aged 16 to 64 . $\mathrm{N}=14,863$. 
Table A3: Prediction Coefficients for Out-of-marriage Labor Earnings Potential

Dependent Variable: In total labor earnings of person $i$

(1) (2)

Females Males

Age (reference: age $<30)$

Age 30-39

$\begin{array}{ll}0.0567 & 0.229 * * \\ (0.0912) & (0.0920) \\ -0.00516 & 0.0935 \\ (0.101) & (0.0915) \\ -0.104 & -0.0161 \\ (0.113) & (0.0921) \\ -0.620 * & -0.346 * * * \\ (0.364) & (0.115)\end{array}$

Education (reference: Master or PhD)

No schooling

$-1.503 * * * \quad-1.026 * * *$

(0.234) (0.249)

Primary school

$-1.252 * * * \quad-1.163 * * *$

(0.172) (0.225)

Middle school

$-1.052 * * * \quad-0.875 * * *$

(0.166) (0.224)

High school

$-0.985 * * * \quad-0.810 * * *$

(0.161) (0.223)

Two-year college

$-0.935 * * *$

$-0.596 * *$

Four-year college

$(0.176)$

(0.234)

$-0.625 * * * \quad-0.617 * * *$

Number of children

(0.190) (0.231)

No of sons ever

$0.00779 \quad 0.0671 * *$

(0.0379) (0.0298)

No of daughters ever

$0.0762 * * \quad 0.0211$

(0.0365) (0.0283)

Province (reference: Seoul)

Busan

$-0.133 * \quad 0.0444$

(0.0753) (0.0690)

Daegu

$0.0495 \quad 0.0167$

(0.112) (0.0969)

Daejon

$-0.237 * * * \quad-0.0366$

(0.0785) (0.0931)

Incheon

$-0.204 * * * \quad-0.0227$

(0.0677) (0.0941)

Gwangju

$-0.337 * * * \quad-0.295 * *$

(0.0923) (0.140)

Ulsan

$0.786 * * * \quad 0.0148$ 


\begin{tabular}{|c|c|c|}
\hline & $(0.228)$ & $(0.180)$ \\
\hline \multirow[t]{2}{*}{ Gyeonggi } & 0.0261 & -0.00801 \\
\hline & $(0.0662)$ & $(0.0607)$ \\
\hline \multirow[t]{2}{*}{ Gangwon } & -0.0989 & 0.0813 \\
\hline & $(0.262)$ & $(0.110)$ \\
\hline \multirow[t]{2}{*}{ Chungcheongbuk } & -0.0201 & $0.144 * *$ \\
\hline & $(0.117)$ & $(0.0706)$ \\
\hline \multirow{2}{*}{ Chungcheongnam } & -0.217 & 0.0826 \\
\hline & $(0.139)$ & $(0.106)$ \\
\hline \multirow[t]{2}{*}{ Jeollabuk } & -0.146 & -0.104 \\
\hline & $(0.161)$ & $(0.0766)$ \\
\hline \multirow[t]{2}{*}{ Jeollanam } & $-0.344 * *$ & 0.0988 \\
\hline & $(0.160)$ & $(0.149)$ \\
\hline \multirow[t]{2}{*}{ Gyeongsangbuk } & -0.00371 & $-0.351 * * *$ \\
\hline & $(0.0961)$ & $(0.106)$ \\
\hline \multirow[t]{2}{*}{ Gyeongsangnam } & 0.118 & 0.119 \\
\hline & $(0.129)$ & $(0.0909)$ \\
\hline \multicolumn{3}{|c|}{ Year (reference: 2003) } \\
\hline \multirow[t]{2}{*}{2004} & -0.0545 & 0.0873 \\
\hline & $(0.0883)$ & $(0.0809)$ \\
\hline \multirow[t]{2}{*}{2005} & -0.0214 & 0.0182 \\
\hline & $(0.0714)$ & $(0.0780)$ \\
\hline \multirow[t]{2}{*}{2006} & 0.0390 & 0.103 \\
\hline & $(0.0775)$ & $(0.0708)$ \\
\hline \multirow[t]{2}{*}{2007} & 0.0219 & 0.0651 \\
\hline & $(0.0770)$ & $(0.0728)$ \\
\hline \multirow[t]{2}{*}{2008} & 0.100 & $0.134 *$ \\
\hline & $(0.0740)$ & $(0.0711)$ \\
\hline \multirow[t]{2}{*}{ Constant } & $5.786^{* * *} *$ & $5.734 * * *$ \\
\hline & $(0.180)$ & $(0.247)$ \\
\hline Observations & 649 & 844 \\
\hline R-squared & 0.243 & 0.206 \\
\hline
\end{tabular}

Note: OLS estimation. Sample of separated, divorced, and remarried. Robust standard errors in parentheses. $* * * \mathrm{p}<0.01, * * \mathrm{p}<0.05, * \mathrm{p}<0.1$ 
Table A4: Prediction Coefficients for Threat Point Life Satisfaction

Dependent variable: Life satisfaction

(1) (2)

Female Male

Age (reference: age <30)

Age 30-39

$\begin{array}{ll}0.0819 & 0.100 \\ (0.162) & (0.136) \\ 0.171 & 0.0806 \\ (0.159) & (0.144) \\ 0.250 & 0.239 \\ (0.167) & (0.146) \\ 0.211 & 0.202 \\ (0.190) & (0.168)\end{array}$

Education (reference: more than high school)

No schooling

$\begin{array}{ll}-0.325 & -1.284 * * * \\ (0.277) & (0.437) \\ -0.0520 & -0.411 * * * \\ (0.107) & (0.112) \\ 0.0491 & -0.228 * * \\ (0.0917) & (0.0974) \\ -0.158 * * & -0.224 * * * \\ (0.0778) & (0.0811)\end{array}$

Health

Health

$\begin{array}{ll}0.210 * * * & 0.208 * * * \\ (0.0315) & (0.0306)\end{array}$

Parental background

Schooling mother

$0.0317 * * * \quad 0.0138$

$\begin{array}{ll}(0.00825) & (0.00857)\end{array}$

Schooling father

$-0.00568 \quad 0.00365$

$(0.00618) \quad(0.00661)$

Economic situation at age 14

$0.0341 \quad 0.0617 * *$

$(0.0278) \quad(0.0258)$

No of children

No of sons ever

$-0.0636^{*} \quad 0.113 * * *$

$(0.0351) \quad(0.0386)$

No of daughters ever

$0.0116 \quad 0.0430$

(0.0260) (0.0363)

Province (reference: Seoul)

Busan

$\begin{array}{ll}-0.0104 & 0.109\end{array}$

$(0.0664) \quad(0.0899)$
0.154

Daegu

$0.154 \quad 0.0877$

$\begin{array}{ll}(0.129) & (0.107)\end{array}$

Daejon

$0.199 \quad 0.0934$ 


\begin{tabular}{|c|c|c|}
\hline & $(0.145)$ & $(0.148)$ \\
\hline Incheon & $\begin{array}{l}0.0877 \\
(0.0989)\end{array}$ & $\begin{array}{l}0.210^{*} \\
(0.122)\end{array}$ \\
\hline Gwangju & $\begin{array}{l}0.359 * * * \\
(0.132)\end{array}$ & $\begin{array}{l}0.660 \\
(0.430)\end{array}$ \\
\hline Ulsan & $\begin{array}{l}0.107 \\
(0.210)\end{array}$ & $\begin{array}{l}0.101 \\
(0.132)\end{array}$ \\
\hline Gyeonggi & $\begin{array}{l}0.0288 \\
(0.0671)\end{array}$ & $\begin{array}{l}0.177 * * \\
(0.0838)\end{array}$ \\
\hline Gangwon & $\begin{array}{l}0.470 * * \\
(0.200)\end{array}$ & $\begin{array}{l}0.480 * * \\
(0.214)\end{array}$ \\
\hline Chungcheongbuk & $\begin{array}{l}-0.265^{* *} \\
(0.131)\end{array}$ & $\begin{array}{l}-0.0415 \\
(0.131)\end{array}$ \\
\hline Chungcheongnam & $\begin{array}{l}0.181 \\
(0.118)\end{array}$ & $\begin{array}{l}0.316^{* *} \\
(0.131)\end{array}$ \\
\hline Jeollabuk & $\begin{array}{l}0.137 \\
(0.217)\end{array}$ & $\begin{array}{l}-0.0913 \\
(0.121)\end{array}$ \\
\hline Jeollanam & $\begin{array}{l}0.159 \\
(0.128)\end{array}$ & $\begin{array}{l}0.551 * * * \\
(0.108)\end{array}$ \\
\hline Gyeongsangbuk & $\begin{array}{l}0.388^{* *} \\
(0.183)\end{array}$ & $\begin{array}{l}0.372 * * * \\
(0.139)\end{array}$ \\
\hline Gyeongsangnam & $\begin{array}{l}0.114 \\
(0.106)\end{array}$ & $\begin{array}{l}0.419 * * * \\
(0.114)\end{array}$ \\
\hline \multicolumn{3}{|c|}{ Year (reference: 2003) } \\
\hline 2004 & $\begin{array}{l}0.0316 \\
(0.0870)\end{array}$ & $\begin{array}{l}-0.0968 \\
(0.0986)\end{array}$ \\
\hline 2005 & $\begin{array}{l}0.0817 \\
(0.0782)\end{array}$ & $\begin{array}{l}-0.00588 \\
(0.0945)\end{array}$ \\
\hline 2006 & $\begin{array}{l}-0.0600 \\
(0.0866)\end{array}$ & $\begin{array}{l}-0.122 \\
(0.0970)\end{array}$ \\
\hline 2007 & $\begin{array}{l}0.112 \\
(0.0822)\end{array}$ & $\begin{array}{l}0.00803 \\
(0.0981)\end{array}$ \\
\hline 2008 & $\begin{array}{l}0.0327 \\
(0.0843)\end{array}$ & $\begin{array}{l}0.0824 \\
(0.0935)\end{array}$ \\
\hline Constant & $\begin{array}{l}1.940 * * * \\
(0.215)\end{array}$ & $\begin{array}{l}1.699 * * * \\
(0.251)\end{array}$ \\
\hline Observations & 664 & 732 \\
\hline R-squared & 0.193 & 0.211 \\
\hline
\end{tabular}

Notes: OLS estimation, sample of separated, divorced, and remarried. Robust standard errors in parentheses. $* * * \mathrm{p}<0.01, * * \mathrm{p}<0.05, * \mathrm{p}<0.1$ 
Table A5: Relative Spousal Earnings Potential, Individual Happiness,

and Intrahousehold Happiness Allocation (all married couples)

\begin{tabular}{|c|c|c|c|c|c|c|c|c|}
\hline & (1) & (2) & (3) & (4) & (5) & (6) & (7) & (8) \\
\hline \multirow[t]{2}{*}{ Dep. Variable: } & $\begin{array}{l}\text { Life sat } \\
\text { husband }\end{array}$ & $\begin{array}{l}\text { Life sat } \\
\text { wife }\end{array}$ & $\begin{array}{l}\text { Life sat } \\
\text { sum } \\
\text { (husb+wife) }\end{array}$ & $\begin{array}{l}\text { Life sat } \\
\text { difference } \\
\text { (husb-wife) }\end{array}$ & $\begin{array}{l}\text { Life sat } \\
\text { husband }\end{array}$ & $\begin{array}{l}\text { Life sat } \\
\text { wife }\end{array}$ & $\begin{array}{l}\text { Life sat } \\
\text { sum } \\
\text { (husb+wife) }\end{array}$ & $\begin{array}{l}\text { Life sat } \\
\text { difference } \\
\text { (husb-wife) }\end{array}$ \\
\hline & OLS & OLS & OLS & OLS & FE & $\mathrm{FE}$ & $\mathrm{FE}$ & FE \\
\hline \multicolumn{9}{|c|}{ Individual and household variables } \\
\hline Ln predicted earnings husband & $\begin{array}{l}0.285^{* * *} \\
(0.0236)\end{array}$ & $\begin{array}{l}0.260 * * * \\
(0.0239)\end{array}$ & $\begin{array}{l}0.545 * * * \\
(0.0409)\end{array}$ & $\begin{array}{l}0.0247 \\
(0.0243)\end{array}$ & $\begin{array}{l}0.108 \\
(0.117)\end{array}$ & $\begin{array}{l}0.140 \\
(0.119)\end{array}$ & $\begin{array}{l}0.248 \\
(0.192)\end{array}$ & $\begin{array}{l}-0.0321 \\
(0.137)\end{array}$ \\
\hline Ln predicted earnings wife & $\begin{array}{l}0.225 * * * \\
(0.0248)\end{array}$ & $\begin{array}{l}0.224 * * * \\
(0.0263)\end{array}$ & $\begin{array}{l}0.449 * * * \\
(0.0431)\end{array}$ & $\begin{array}{l}0.00162 \\
(0.0274)\end{array}$ & $\begin{array}{l}-0.0787 \\
(0.106)\end{array}$ & $\begin{array}{l}0.184^{*} \\
(0.108)\end{array}$ & $\begin{array}{l}0.105 \\
(0.174)\end{array}$ & $\begin{array}{l}-0.262 * * \\
(0.125)\end{array}$ \\
\hline Ln per-capita hh income & $\begin{array}{l}0.144 * * * \\
(0.00726)\end{array}$ & $\begin{array}{l}0.156 * * * \\
(0.00740)\end{array}$ & $\begin{array}{l}0.300 * * * \\
(0.0130)\end{array}$ & $\begin{array}{l}-0.0113^{*} \\
(0.00681)\end{array}$ & $\begin{array}{l}0.0464 * * * \\
(0.00798)\end{array}$ & $\begin{array}{l}0.0479 * * * \\
(0.00810)\end{array}$ & $\begin{array}{l}0.0943 * * * \\
(0.0131)\end{array}$ & $\begin{array}{l}-0.00152 \\
(0.00935)\end{array}$ \\
\hline $\begin{array}{l}\text { Ln per-capita hh income } \\
\text { (provincial average) }\end{array}$ & $\begin{array}{l}-0.204 * * \\
(0.101)\end{array}$ & $\begin{array}{l}-0.340 * * * \\
(0.102)\end{array}$ & $\begin{array}{l}-0.544 * * * \\
(0.176)\end{array}$ & $\begin{array}{l}0.137 \\
(0.102)\end{array}$ & $\begin{array}{l}-0.0997 \\
(0.0938)\end{array}$ & $\begin{array}{l}-0.315^{* * *} \\
(0.0953)\end{array}$ & $\begin{array}{l}-0.415 * * * \\
(0.154)\end{array}$ & $\begin{array}{l}0.215^{*} \\
(0.110)\end{array}$ \\
\hline Duration of marriage & $\begin{array}{l}-0.00188 \\
(0.00133)\end{array}$ & $\begin{array}{l}-0.00357 * * * \\
(0.00135)\end{array}$ & $\begin{array}{l}-0.00545^{* *} \\
(0.00229)\end{array}$ & $\begin{array}{l}0.00170 \\
(0.00141)\end{array}$ & $\begin{array}{l}-0.105 * * \\
(0.0448)\end{array}$ & $\begin{array}{l}-0.0959 * * \\
(0.0455)\end{array}$ & $\begin{array}{l}-0.201 * * * \\
(0.0734)\end{array}$ & $\begin{array}{l}-0.00952 \\
(0.0525)\end{array}$ \\
\hline Health husband & $\begin{array}{l}0.158^{* * *} \\
(0.00773)\end{array}$ & $\begin{array}{l}0.0887 * * * \\
(0.00751)\end{array}$ & $\begin{array}{l}0.247 * * * \\
(0.0131)\end{array}$ & $\begin{array}{l}0.0696 * * * \\
(0.00780)\end{array}$ & $\begin{array}{l}0.131 * * * \\
(0.00810)\end{array}$ & $\begin{array}{l}0.0491 * * * \\
(0.00823)\end{array}$ & $\begin{array}{l}0.180 * * * \\
(0.0133)\end{array}$ & $\begin{array}{l}0.0822 * * * \\
(0.00950)\end{array}$ \\
\hline Health wife & $\begin{array}{l}0.0707 * * * \\
(0.00719)\end{array}$ & $\begin{array}{l}0.130 * * * \\
(0.00737)\end{array}$ & $\begin{array}{l}0.200^{* * *} \\
(0.0124)\end{array}$ & $\begin{array}{l}-0.0590 * * * \\
(0.00768)\end{array}$ & $\begin{array}{l}0.0458^{* * *} \\
(0.00801)\end{array}$ & $\begin{array}{l}0.114 * * * \\
(0.00814)\end{array}$ & $\begin{array}{l}0.160 * * * \\
(0.0131)\end{array}$ & $\begin{array}{l}-0.0680 * * * \\
(0.00939)\end{array}$ \\
\hline Age 30-39 wife & $\begin{array}{l}-0.0256 \\
(0.0199)\end{array}$ & $\begin{array}{l}-0.0404 * \\
(0.0207)\end{array}$ & $\begin{array}{l}-0.0660^{*} \\
(0.0340)\end{array}$ & $\begin{array}{l}0.0148 \\
(0.0221)\end{array}$ & $\begin{array}{l}0.00875 \\
(0.0299)\end{array}$ & $\begin{array}{l}-0.0165 \\
(0.0304)\end{array}$ & $\begin{array}{l}-0.00776 \\
(0.0490)\end{array}$ & $\begin{array}{l}0.0253 \\
(0.0350)\end{array}$ \\
\hline Age $40-49$ wife & $\begin{array}{l}-0.0300 \\
(0.0277)\end{array}$ & $\begin{array}{l}-0.0305 \\
(0.0283)\end{array}$ & $\begin{array}{l}-0.0604 \\
(0.0473)\end{array}$ & $\begin{array}{l}0.000509 \\
(0.0300)\end{array}$ & $\begin{array}{l}0.0116 \\
(0.0400)\end{array}$ & $\begin{array}{l}0.0268 \\
(0.0406)\end{array}$ & $\begin{array}{l}0.0384 \\
(0.0656)\end{array}$ & $\begin{array}{l}-0.0152 \\
(0.0468)\end{array}$ \\
\hline Age 50-59 wife & $\begin{array}{l}0.0154 \\
(0.0362)\end{array}$ & $\begin{array}{l}0.0108 \\
(0.0366)\end{array}$ & $\begin{array}{l}0.0262 \\
(0.0619)\end{array}$ & $\begin{array}{l}0.00462 \\
(0.0384)\end{array}$ & $\begin{array}{l}0.00856 \\
(0.0522)\end{array}$ & $\begin{array}{l}0.0165 \\
(0.0531)\end{array}$ & $\begin{array}{l}0.0250 \\
(0.0857)\end{array}$ & $\begin{array}{l}-0.00789 \\
(0.0612)\end{array}$ \\
\hline Age $60+$ wife & $\begin{array}{l}0.165 * * * \\
(0.0529)\end{array}$ & $\begin{array}{l}0.156 * * * \\
(0.0544)\end{array}$ & $\begin{array}{l}0.321 * * * \\
(0.0909)\end{array}$ & $\begin{array}{l}0.00952 \\
(0.0569)\end{array}$ & $\begin{array}{l}-0.0905 \\
(0.0997)\end{array}$ & $\begin{array}{l}0.120 \\
(0.101)\end{array}$ & $\begin{array}{l}0.0298 \\
(0.164)\end{array}$ & $\begin{array}{l}-0.211^{*} \\
(0.117)\end{array}$ \\
\hline
\end{tabular}




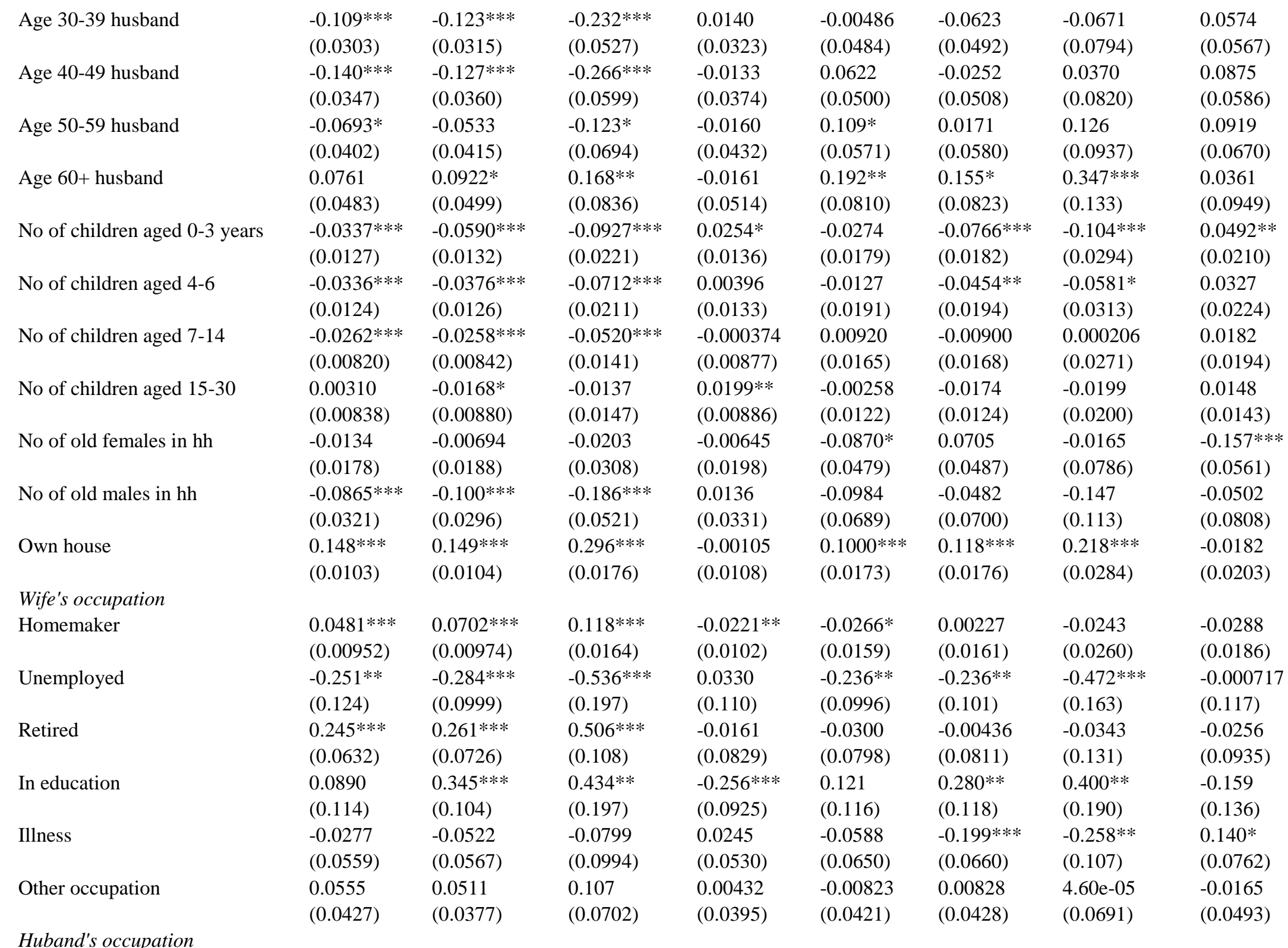




\begin{tabular}{|c|c|c|c|c|c|c|c|c|}
\hline Homemaker & $\begin{array}{l}0.0167 \\
(0.0765)\end{array}$ & $\begin{array}{l}0.0369 \\
(0.0701)\end{array}$ & $\begin{array}{l}0.0536 \\
(0.132)\end{array}$ & $\begin{array}{l}-0.0201 \\
(0.0647)\end{array}$ & $\begin{array}{l}-0.0549 \\
(0.0743)\end{array}$ & $\begin{array}{l}0.0592 \\
(0.0755)\end{array}$ & $\begin{array}{l}0.00436 \\
(0.122)\end{array}$ & $\begin{array}{l}-0.114 \\
(0.0871)\end{array}$ \\
\hline Unemployed & $\begin{array}{l}-0.408 * * * \\
(0.0394)\end{array}$ & $\begin{array}{l}-0.401 * * * \\
(0.0393)\end{array}$ & $\begin{array}{l}-0.808 * * * \\
(0.0681)\end{array}$ & $\begin{array}{l}-0.00699 \\
(0.0393)\end{array}$ & $\begin{array}{l}-0.303 * * * \\
(0.0384)\end{array}$ & $\begin{array}{l}-0.326 \text { *** } \\
(0.0390)\end{array}$ & $\begin{array}{l}-0.629 * * * \\
(0.0629)\end{array}$ & $\begin{array}{l}0.0225 \\
(0.0450)\end{array}$ \\
\hline Retired & $\begin{array}{l}0.0590 \\
(0.0374)\end{array}$ & $\begin{array}{l}0.0255 \\
(0.0390)\end{array}$ & $\begin{array}{l}0.0845 \\
(0.0661)\end{array}$ & $\begin{array}{l}0.0335 \\
(0.0383)\end{array}$ & $\begin{array}{l}-0.0298 \\
(0.0472)\end{array}$ & $\begin{array}{l}-0.0521 \\
(0.0479)\end{array}$ & $\begin{array}{l}-0.0818 \\
(0.0774)\end{array}$ & $\begin{array}{l}0.0223 \\
(0.0553)\end{array}$ \\
\hline In education & $\begin{array}{l}0.0587 \\
(0.0916)\end{array}$ & $\begin{array}{l}0.00670 \\
(0.110)\end{array}$ & $\begin{array}{l}0.0654 \\
(0.137)\end{array}$ & $\begin{array}{l}0.0520 \\
(0.148)\end{array}$ & $\begin{array}{l}-0.00851 \\
(0.137)\end{array}$ & $\begin{array}{l}-0.311^{* *} \\
(0.139)\end{array}$ & $\begin{array}{l}-0.320 \\
(0.225)\end{array}$ & $\begin{array}{l}0.303^{*} \\
(0.161)\end{array}$ \\
\hline Illness & $\begin{array}{l}-0.0332 \\
(0.0367)\end{array}$ & $\begin{array}{l}-0.0812^{* *} \\
(0.0341)\end{array}$ & $\begin{array}{l}-0.114 * \\
(0.0602)\end{array}$ & $\begin{array}{l}0.0480 \\
(0.0375)\end{array}$ & $\begin{array}{l}-0.0894 * * \\
(0.0424)\end{array}$ & $\begin{array}{l}-0.118^{* * * *} \\
(0.0431)\end{array}$ & $\begin{array}{l}-0.208 * * * \\
(0.0696)\end{array}$ & $\begin{array}{l}0.0289 \\
(0.0497)\end{array}$ \\
\hline Other occupation & $\begin{array}{l}-0.0882 * * * \\
(0.0210)\end{array}$ & $\begin{array}{l}-0.0985 * * * \\
(0.0201)\end{array}$ & $\begin{array}{l}-0.187 * * * \\
(0.0353)\end{array}$ & $\begin{array}{l}0.0103 \\
(0.0211)\end{array}$ & $\begin{array}{l}-0.0800 * * * \\
(0.0242)\end{array}$ & $\begin{array}{l}-0.100 * * * \\
(0.0246)\end{array}$ & $\begin{array}{l}-0.180 * * * \\
(0.0396)\end{array}$ & $\begin{array}{l}0.0203 \\
(0.0283)\end{array}$ \\
\hline Province of resider & & & & & & & & \\
\hline Busan & $\begin{array}{l}0.0478 * \\
(0.0257)\end{array}$ & $\begin{array}{l}-0.0165 \\
(0.0262)\end{array}$ & $\begin{array}{l}0.0313 \\
(0.0445)\end{array}$ & $\begin{array}{l}0.0643 * * \\
(0.0269)\end{array}$ & $\begin{array}{l}-0.0353 \\
(0.137)\end{array}$ & $\begin{array}{l}0.119 \\
(0.139)\end{array}$ & $\begin{array}{l}0.0838 \\
(0.225)\end{array}$ & $\begin{array}{l}-0.154 \\
(0.160)\end{array}$ \\
\hline Daegu & $\begin{array}{l}0.0758 * * \\
(0.0351)\end{array}$ & $\begin{array}{l}0.0336 \\
(0.0358)\end{array}$ & $\begin{array}{l}0.109 * \\
(0.0612)\end{array}$ & $\begin{array}{l}0.0421 \\
(0.0358)\end{array}$ & $\begin{array}{l}0.232 \\
(0.150)\end{array}$ & $\begin{array}{l}0.281 * \\
(0.152)\end{array}$ & $\begin{array}{l}0.513 * * \\
(0.246)\end{array}$ & $\begin{array}{l}-0.0496 \\
(0.176)\end{array}$ \\
\hline Daejon & $\begin{array}{l}0.119 * * * \\
(0.0245)\end{array}$ & $\begin{array}{l}0.107 * * * \\
(0.0254)\end{array}$ & $\begin{array}{l}0.227 * * * \\
(0.0429)\end{array}$ & $\begin{array}{l}0.0120 \\
(0.0256)\end{array}$ & $\begin{array}{l}0.419 * * * \\
(0.150)\end{array}$ & $\begin{array}{l}0.0421 \\
(0.153)\end{array}$ & $\begin{array}{l}0.461 * \\
(0.247)\end{array}$ & $\begin{array}{l}0.377 * * \\
(0.176)\end{array}$ \\
\hline Incheon & $\begin{array}{l}0.0676 * * \\
(0.0300)\end{array}$ & $\begin{array}{l}0.0623 * * \\
(0.0307)\end{array}$ & $\begin{array}{l}0.130 * * \\
(0.0516)\end{array}$ & $\begin{array}{l}0.00523 \\
(0.0320)\end{array}$ & $\begin{array}{l}0.0662 \\
(0.107)\end{array}$ & $\begin{array}{l}0.109 \\
(0.108)\end{array}$ & $\begin{array}{l}0.175 \\
(0.175)\end{array}$ & $\begin{array}{l}-0.0426 \\
(0.125)\end{array}$ \\
\hline Gwangju & $\begin{array}{l}0.242^{* * * *} \\
(0.0339)\end{array}$ & $\begin{array}{l}0.194 * * * \\
(0.0352)\end{array}$ & $\begin{array}{l}0.436 * * * \\
(0.0565)\end{array}$ & $\begin{array}{l}0.0478 \\
(0.0397)\end{array}$ & $\begin{array}{l}0.316^{* *} \\
(0.161)\end{array}$ & $\begin{array}{l}0.239 \\
(0.164)\end{array}$ & $\begin{array}{l}0.555^{* *} \\
(0.265)\end{array}$ & $\begin{array}{l}0.0779 \\
(0.189)\end{array}$ \\
\hline Ulsan & $\begin{array}{l}-0.150 * * * \\
(0.0331)\end{array}$ & $\begin{array}{l}-0.143 * * * \\
(0.0347)\end{array}$ & $\begin{array}{l}-0.293 * * * \\
(0.0578)\end{array}$ & $\begin{array}{l}-0.00663 \\
(0.0354)\end{array}$ & $\begin{array}{l}0.122 \\
(0.180)\end{array}$ & $\begin{array}{l}0.0144 \\
(0.183)\end{array}$ & $\begin{array}{l}0.136 \\
(0.295)\end{array}$ & $\begin{array}{l}0.108 \\
(0.211)\end{array}$ \\
\hline Gyeonggi & $\begin{array}{l}0.0471 * * * \\
(0.0138)\end{array}$ & $\begin{array}{l}0.0600 * * * \\
(0.0140)\end{array}$ & $\begin{array}{l}0.107 * * * \\
(0.0236)\end{array}$ & $\begin{array}{l}-0.0128 \\
(0.0148)\end{array}$ & $\begin{array}{l}0.0341 \\
(0.0493)\end{array}$ & $\begin{array}{l}-0.00568 \\
(0.0501)\end{array}$ & $\begin{array}{l}0.0284 \\
(0.0810)\end{array}$ & $\begin{array}{l}0.0398 \\
(0.0578)\end{array}$ \\
\hline Gangwon & $\begin{array}{l}0.0605 \\
(0.0502)\end{array}$ & $\begin{array}{l}-0.00282 \\
(0.0503)\end{array}$ & $\begin{array}{l}0.0577 \\
(0.0883)\end{array}$ & $\begin{array}{l}0.0633 \\
(0.0482)\end{array}$ & $\begin{array}{l}0.428 * * * \\
(0.163)\end{array}$ & $\begin{array}{l}0.231 \\
(0.166)\end{array}$ & $\begin{array}{l}0.660^{* * *} \\
(0.267)\end{array}$ & $\begin{array}{l}0.197 \\
(0.191)\end{array}$ \\
\hline Chungcheongbuk & $\begin{array}{l}-0.100 * * * \\
(0.0347)\end{array}$ & $\begin{array}{l}-0.0817 * * \\
(0.0371)\end{array}$ & $\begin{array}{l}-0.182 * * * \\
(0.0612)\end{array}$ & $\begin{array}{l}-0.0187 \\
(0.0375)\end{array}$ & $\begin{array}{l}0.194 \\
(0.168)\end{array}$ & $\begin{array}{l}-0.141 \\
(0.171)\end{array}$ & $\begin{array}{l}0.0530 \\
(0.276)\end{array}$ & $\begin{array}{l}0.334^{*} \\
(0.197)\end{array}$ \\
\hline Chungcheongnam & $\begin{array}{l}0.0424 \\
(0.0421)\end{array}$ & $\begin{array}{l}0.0263 \\
(0.0429)\end{array}$ & $\begin{array}{l}0.0687 \\
(0.0729)\end{array}$ & $\begin{array}{l}0.0161 \\
(0.0438)\end{array}$ & $\begin{array}{l}0.0587 \\
(0.130)\end{array}$ & $\begin{array}{l}-0.0387 \\
(0.133)\end{array}$ & $\begin{array}{l}0.0199 \\
(0.214)\end{array}$ & $\begin{array}{l}0.0974 \\
(0.153)\end{array}$ \\
\hline Jeollabuk & $\begin{array}{l}0.233 * * * \\
(0.0338)\end{array}$ & $\begin{array}{l}0.147 * * * \\
(0.0363)\end{array}$ & $\begin{array}{l}0.380 * * * \\
(0.0605)\end{array}$ & $\begin{array}{l}0.0859 * * \\
(0.0355)\end{array}$ & $\begin{array}{l}0.324 * * \\
(0.147)\end{array}$ & $\begin{array}{l}0.259^{*} \\
(0.150)\end{array}$ & $\begin{array}{l}0.583 * * \\
(0.242)\end{array}$ & $\begin{array}{l}0.0655 \\
(0.173)\end{array}$ \\
\hline Jeollanam & $0.213 * * *$ & $0.194 * * *$ & $0.408 * * *$ & 0.0191 & 0.286 & $0.370^{*}$ & $0.656^{* *}$ & -0.0842 \\
\hline
\end{tabular}




\begin{tabular}{|c|c|c|c|c|c|c|c|c|}
\hline & $(0.0341)$ & $(0.0346)$ & $(0.0584)$ & $(0.0363)$ & $(0.193)$ & $(0.196)$ & $(0.316)$ & $(0.226)$ \\
\hline \multirow[t]{2}{*}{ Gyeongsangbuk } & $0.182 * * *$ & $0.155^{* * * *}$ & $0.337 * * *$ & 0.0277 & $0.352 * *$ & 0.00120 & 0.353 & $0.350 * *$ \\
\hline & $(0.0484)$ & $(0.0485)$ & $(0.0831)$ & $(0.0499)$ & $(0.148)$ & $(0.150)$ & $(0.242)$ & $(0.173)$ \\
\hline \multirow[t]{2}{*}{ Gyeongsangnam } & $0.0854 * * *$ & 0.0391 & $0.125 * * *$ & $0.0463 *$ & 0.134 & -0.00412 & 0.130 & 0.138 \\
\hline & $(0.0251)$ & $(0.0255)$ & $(0.0427)$ & $(0.0271)$ & $(0.126)$ & $(0.128)$ & $(0.206)$ & $(0.147)$ \\
\hline \multicolumn{9}{|l|}{ Year effects } \\
\hline \multirow[t]{2}{*}{2004} & -0.00204 & 0.00539 & 0.00335 & -0.00744 & $0.0805^{*}$ & $0.0918 *$ & $0.172 * *$ & -0.0113 \\
\hline & $(0.0173)$ & $(0.0180)$ & $(0.0304)$ & $(0.0180)$ & $(0.0487)$ & $(0.0495)$ & $(0.0799)$ & $(0.0571)$ \\
\hline \multirow[t]{2}{*}{2005} & 0.0138 & $0.0405 * *$ & $0.0543 *$ & -0.0267 & $0.196 * *$ & $0.216 * *$ & $0.413 * * *$ & -0.0197 \\
\hline & $(0.0175)$ & $(0.0180)$ & $(0.0304)$ & $(0.0183)$ & $(0.0881)$ & $(0.0895)$ & $(0.144)$ & $(0.103)$ \\
\hline \multirow[t]{2}{*}{2006} & 0.00515 & 0.0277 & 0.0328 & -0.0225 & $0.324 * *$ & $0.315^{* *}$ & $0.639 * * *$ & 0.00846 \\
\hline & $(0.0249)$ & $(0.0255)$ & $(0.0433)$ & $(0.0257)$ & $(0.136)$ & $(0.138)$ & $(0.223)$ & $(0.159)$ \\
\hline \multirow[t]{2}{*}{2007} & 0.0286 & $0.0619 * *$ & $0.0905^{*}$ & -0.0332 & $0.431 * *$ & $0.434 * *$ & $0.865 * * *$ & -0.00240 \\
\hline & $(0.0295)$ & $(0.0300)$ & $(0.0514)$ & $(0.0300)$ & $(0.179)$ & $(0.181)$ & $(0.293)$ & $(0.209)$ \\
\hline \multirow[t]{2}{*}{2008} & 0.0246 & 0.0433 & 0.0678 & -0.0187 & $0.576^{* *}$ & $0.527 * *$ & $1.103 * * *$ & 0.0486 \\
\hline & $(0.0279)$ & $(0.0283)$ & $(0.0487)$ & $(0.0282)$ & $(0.227)$ & $(0.231)$ & $(0.373)$ & $(0.266)$ \\
\hline \multirow[t]{2}{*}{ Constant } & 0.226 & $1.003 * *$ & 1.229 & -0.777 & $4.109 * * *$ & $3.635 * * *$ & $7.744 * * *$ & 0.474 \\
\hline & $(0.479)$ & $(0.486)$ & $(0.833)$ & $(0.486)$ & $(1.097)$ & $(1.115)$ & $(1.800)$ & $(1.286)$ \\
\hline Couple observations & 14,863 & 14,863 & 14,863 & 14,863 & 14,863 & 14,863 & 14,863 & 14,863 \\
\hline No of couples & 3,542 & 3,542 & 3,542 & 3,542 & 3,542 & 3,542 & 3,542 & 3,542 \\
\hline
\end{tabular}

Notes: Linear fixed effects estimation. Robust standard errors in parentheses. *** $\mathrm{p}<0.01$, ** $\mathrm{p}<0.05$, * $\mathrm{p}<0.1$. 
Figure A1: Wife's Share in Total Predicted Earnings and Relative Spousal Happiness

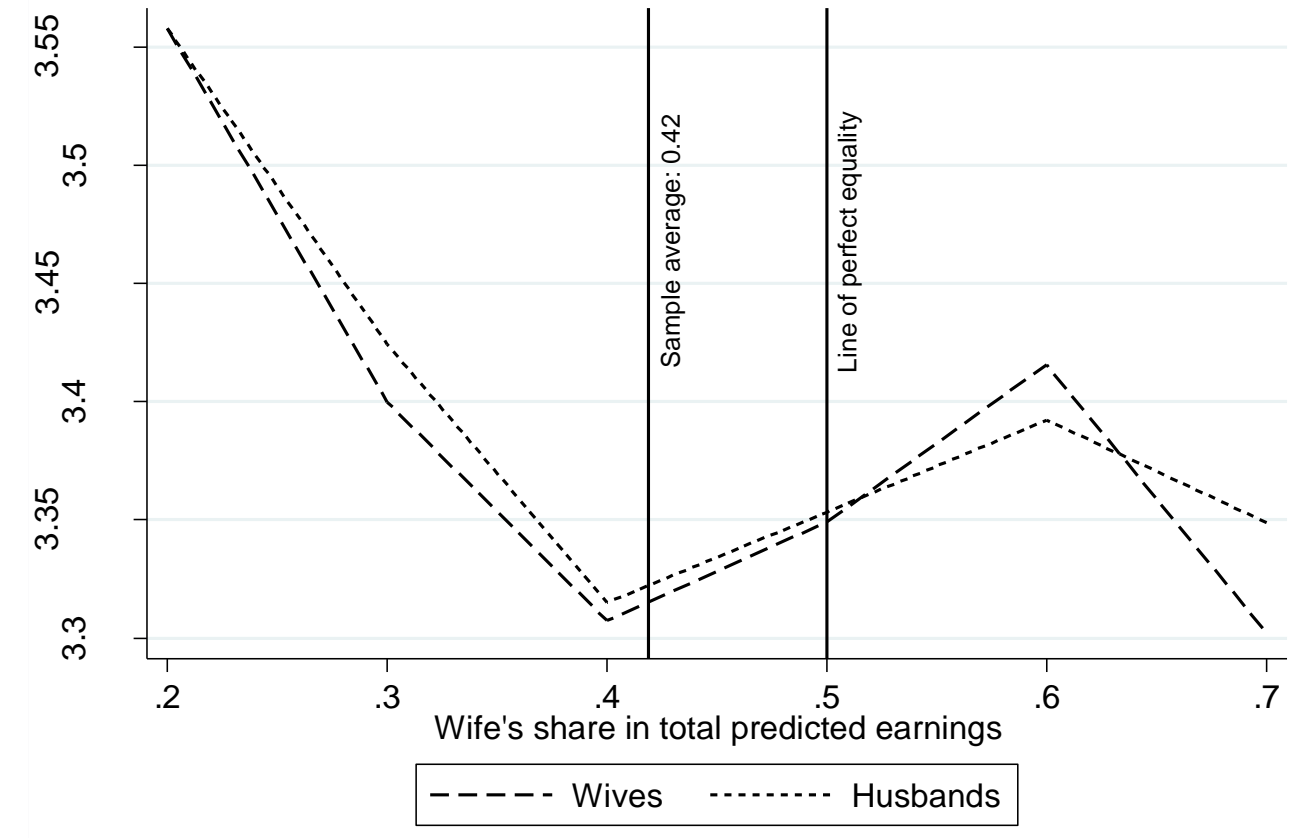

